\title{
UNITED STATES DEPARTMENT OF THE INTERIOR GEOLOGICAL SURVEY
}

\section{Uranium and thorium in granitic rocks of northeastern Washington and northern Idaho, with camments on uranium resource potential}

\section{By}

J. Thomas Nash

Open-File Report 79-233

1979

This report is preliminary and has not been edited or reviewed for conformity with U.S. Geological Survey standards. 
CONTENTS

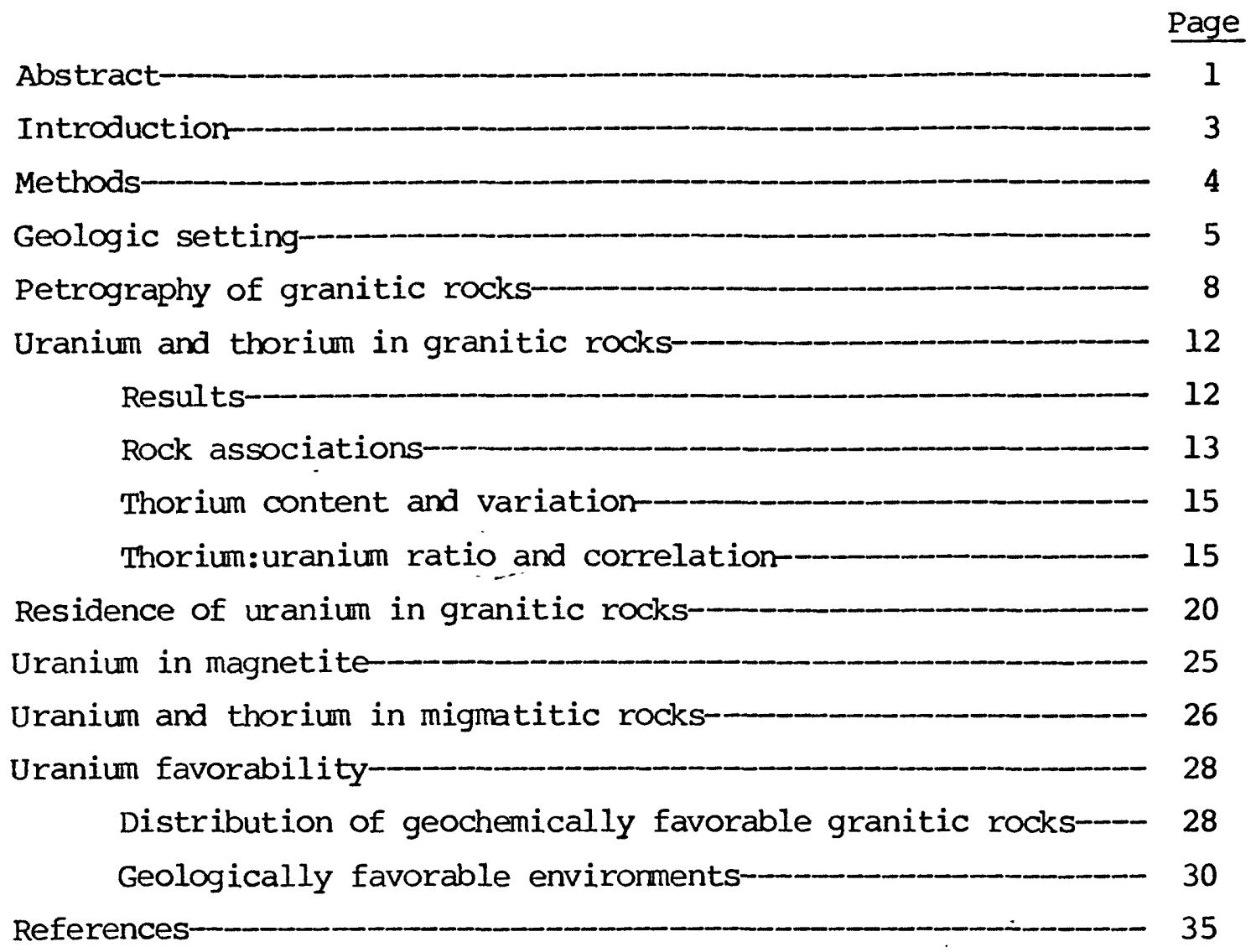




\section{List of illustrations}

Page

Figure 1. Variation of uranium and thorium in two

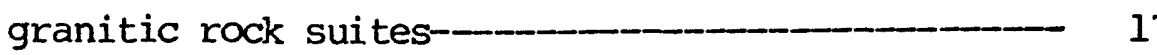

2. Photograph of fission tracks produced by uranium

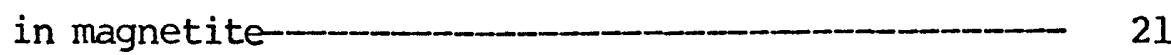

3. Photographs of thin sections and fission track maps- 22

4. Photographs of thin sections and fission track maps- 24

5. Simplified geologic map showing anomalous sample

localities and anomalous plutons-_____ 29

Plate 1. Geologic map of plutonic rocks showing location of

samples collected for this study-_-

Tables

Table 1. Analytical data for samples of granitic rock-_-_- 7

2. Chemical analyses and CIPW norms of granitic rocks-- 11

3. Statistics for uranium and thorium in plutonic

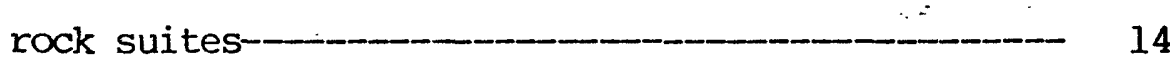

4. Mineralogy of uraniferous migmatites-_-_- 27 
Uranium and Thorium in Granitic Rocks of Northeastern

Washington and Northern Idaho, with comments on

Uranium Resource Potential

by J. Thomas Nash

ABSTRACT

Northeastern Washington and northern Idaho is a uranium province in which many Cretaceous and Tertiary granitic plutons contain abnormal amounts of uranium. Mean uranium content of 108 samples of granitic rock is 8.8 parts per million (ppm), more than twice normal for rocks of this composition. The mean thorium content, $20.3 \mathrm{ppm}$, and mean $T h / \mathrm{J}, 3.19$, are nomal. The most uraniferous and fertile rocks are the peraluminous twomica granitic suite, although not all two-mica plutons are enriched in uranium. The muscovite-bearing suite has mean uranium content of 22.3 ppm, mean thorium content of $22.8 \mathrm{ppm}$, and mean $\mathrm{Th} / \mathrm{J}$ of 2.82. Porphyritic quartz monzonite of the Midnite mine, which I interpret to be a two-mica granitic rock, is especially radioactive with mean $U$ of 14.7 ppm, mean Th of $32.1 \mathrm{ppm}$, and mean $\mathrm{Th} / \mathrm{U}$ of 2.72. Mean uranium and thorium contents of the two-mica granitic plutons are significantly different from those of the calcalkaline hornblende granitic suite, which are mean U, $5.0 \mathrm{ppm}$; mean Th, 17.6; and mean $T h / N, 3.78$. Biotite granitic rocks containing no hornblende or muscovite appear to be an intermediate suite in terms of $U$ and Th, or possibly are variants of both hornblende and muscovite type; mean $U$ is $3.88 \mathrm{ppm}$, mean $T h$ is $14.4 \mathrm{ppm}$, and mean $T h / U$ is 3.03 as calculated from the more abundant data of Castor and others (1978).

Occurrence of uranium and thorium in the muscovite and hornblende suites is systematically different. Many muscovite-bearing rocks are much more enriched in uranium ( $>15 \mathrm{ppm}$ ) than they are in thorium, and have a relatively low Th:U correlation coefficient of t0.409. Many of the uraniferous muscovite-bearing rocks contain less than $20 \mathrm{ppm}$ Th, probably a consequence of forming by anatexis of thorium deficient sedimentary rocks. Uranium and thorium variation is much more regular in the hornblende suite, which has a Th:U correlation coefficient of +0.780 . uranium in the muscovite suite is held primarily in magnetite and biotite, and possibly as minute uraninite grains, whereas in the hornblende suite uranium resides primarily in sphene, zircon, and allanite. Many muscovite-bearing plutons are considered fertile by the following two 
criteria: high uranium content, and uranium residence in labile phases. The hornblende-bearing granitic plutons are not considered fertile, regardless of uranium content, because uranium resides in refractory phases.

Twenty-one sample localities in four plutons are considered highly anomalous according to one or more of the following attributes: (1) Uranium content $\leqslant 15.8 \mathrm{ppm}$ (total population mean plus $1 \sigma$ ). (2) Thorium

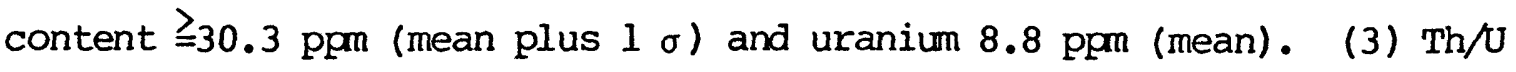
lower than 1.68 (mean minus $1 \sigma$ ) and uranium content $\geqq 8.8 \mathrm{ppm}$. The four identified highly anomalous plutons are, from southwest to northeast, (1) Cretaceous porphyritic quartz monzonite of the Midnite mine; (2) Cretaceous muscovite quartz monzonite east of Deer Lake; (3) Cretaceous quartz monzonite of Hungry Mountain, and (4) Cretaceous quartz monzonite of Granite Pass.

The study area is favorable for at least five types of uranium deposits including: intragranitic hydrothemal veins as in the Massif Central, France; intragranitic supergene veins, as at the Daybreak mine; contact zone deposits, as at the Midnite mine; and basal-type sandstone deposits, as at the Sherwood mine. The fifth type is Rossing-type deposits for which the high-grade metamorphic terrane of the Kettle River Range, Ferry County, seems favorable, if sufficient volume of low-tenor rock can be located. The first four deposit types seem most likely in or adjacent to uraniferous plutons, as no other uranium source rocks have been identified in the area. Contact zone deposits and intragranitic hydrothemal veins, both possibly supergene-enriched, and basal-type deposits in Tertiary sandstone and conglamerate, seem most likely to be of economic importance. Exploration and discovery of potential uranium depositions in the area is severely hampered by deep weathering, glacial cover, and poorly exposed structure. 


\section{INTRODUCTION}

Delineation of areas or provinces rich in uranium is one reconnaissance technique in uranium exploration and resource assessment. Many uranium-producing districts in the world are located in, or adjacent to, uranium-rich bassement rocks (Dodson and others, 1974; Darnley and others, 1977; Poty and others, 1977), although some doubt the validity of this association (Nininger, 1977). This study was undertaken to document the distribution of uranium and thorium in plutonic rocks as a possible general guide to uranium deposits within the plutons (for example, intragranitic vein deposits of the French type), adjacent to the plutons in contact zones (as at the Midnite mine, Washington), or in nearby sedimentary rocks (as at the Sherwood mine, Washington). It is believed that the uranium-rich plutons described here are possible indicators or sources for magmatic, hydrothermal, or supergene deposits.

This report is intended to be used in conjunction with the report of Castor and others (1978). They summarize uranium and thorium and petrographic data for 344 plutonic rock samples collected over a much larger area than I investigated. My sample localities are plotted (Plate 1) on Castor's base map to permit easier use and comparison of the two data sets. Other data for radioelement content of plutonic rocks are in Munroe and others (1975), and Marjaniemi and Basler (1972), both of which are summarized in Castor and others (1977). 


\section{METHODS}

Data for 108 rock samples are reported in table 1. These are grab and composite samples collected during the period April 1974 to August 1977. They represent the freshest possible rock, generally fram roadcuts, that I could locate in an area. Nine samples of uranium-rich rocks from migmatite terrane of Ferry county are included even though they are more properly considered to be metamorphic rocks. All but the 9 metamorphicrock samples are considered to be representative of larger volumes of rock on the basis of broad-band gamma scintillometer measurements. Field measurement of uranium and thorium was attempted with a gamma spectrometer on a $442 \mathrm{~cm}^{3}$ crystal but it was found to be impractical in most situations because of irregular geometry of fresh sample exposures.

All but six samples were studied petrographically to establish the degree of alteration and to determine muscovite and amphibole content. On the basis of field appearance and thin-section study all rocks analyzed (table 1) are considered to be very fresh unless otherwise noted; feldspars contain only traces of argillic alteration and biotites contain minor amounts of chlorite. Thin sections of 34 samples were studied by the fission track map technique to determine the distribution of uranium and its mineralogical residence. A muscovite detector with very low uranium content was placed next to uncovered thin sections and irradiated in a reactor at $100 \mathrm{kw}$ for 3 hours. Induced fission tracks of ${ }^{235} \mathrm{U}$ were developed in the muscovite detectors by etching in 48 percent HF for 15 seconds.

Most samples were analyzed for uranium and thorium by the delayed neutron technique. Approximately 10 grams of powder was obtained by splitting a ground sample of about 600 to 800 grams or by taking chips from a large sample. Twenty-eight samples were analyzed by gamma spectrometry for radium equivalent uranium, thorium, and potassium. Analytical methods are described in more detail by Stuckless, and others (1977B). 
The geology of Mesozoic and lower Cenozoic plutonic rocks of most of the study area as been ably mapped and discussed by F. K. Miller in several reports (Miller and Clark, 1975; Miller and Engels, 1975; Miller, 1974a, b, c, d; Miller and Yates, 1976). Three general periods of plutonism occurred in the study area: a small volume at about 200 million years (m.y.) ago; a large volume at about $100 \mathrm{~m} . \mathrm{y}$. ago, and a slightly smaller volume of about $50 \mathrm{~m} \cdot \mathrm{y}$. ago. The $200 \mathrm{~m} \cdot \mathrm{y}$. plutonism produced hornblende-biotite granodiorite, whereas the 100 and $50 \mathrm{~m} \cdot \mathrm{y}$. plutonism produced both hornblende-biotite granodiorite and quartz monzonite and muscovite-biotite (two mica) quartz monzonite. Miller rightly emphasized the contrasting hornblende-bearing and muscovite-bearing suites. This fundamental petrochemical distinction appears to be important in the recognition of uranium-rich plutons, and will be emphasized in this report. The plutons of the episodes dated at $100 \mathrm{~m} . \mathrm{y}$. and $50 \mathrm{~m} . \mathrm{y}$. have structural and textural features considered typical of mesozonal granitoid rocks (Buddington, 1959). Some of the plutons are zoned, but none are known to exhibit mineral zoning indicative of transition between the hornblende-suite and the muscovite-suite (F.K. Miller, oral cammun., 1978). Most of the muscovite-bearing plutons exhibit considerable local textural variability with zones of pegmatite and aplite.

The chemical composition (Si-Al-rich; Fe-Mg-poor) and mineralogy (muscovite present; hornblende absent) of the muscovite-bearing two-mica plutons places them in the S-type category of granitoid rocks (Chappel and White, 1974; White and Chappel, 1977). Rocks of this composition are believed to have been formed by anatexis of sedimentary rocks. The hornblende-bearing suite have compositions characteristic of I-type granitoid rocks that could be generated by melting of igneous rocks. These petrogenetic differences are useful in understanding possible mechanisms of uranium enrichment.

Geology west of the Columbia River in Ferry County differs from that to the east in many important aspects and is poorly understood. The Kettle River Range contains the Precambrian(?) or Paleozoic(?) metasedimentary rock sequence comprising thick quartzite, carbonate, and shale units (Pearson, 1977) that probably correlate with 
the Shuswap Formation as defined on strike in British Comumbia. These sedimentary rocks are metamorphosed to medium and high grades and locally migmatite is developed. There are many zones of cataclasis and gneissic texture is developed in the Mesozoic(?) Cascade Granodiorite (Pearson, 1977). The western edge of the metamorphic complex is described by Parker and Calkins (1964) and by Muessig (1967), and the north central area was mapped by pearson (1977).

Numerous uranium occurrences in the metamorphic complex have been described by Barlow (1958), and a new interpretation of the structural localization of uranium deposits given by Cheney (1977). Most uranium occurrences are in mixed biotite schists and leucocratic "pegmatites" (term of Barlow, 1958) that are best termed migmatite. These rocks have lithologies similar to those reported in the Rossing uranium area, S.W. Africa (Berning and others, 1976), but the thickness of melted leucocratic rocks is generally less than $5 \mathrm{~m}$, hence there is no known large volume of uraniferous alaskite as at Rossing. Radioelement analyses of nine samples of these metamorphic rocks are included in table 1. 


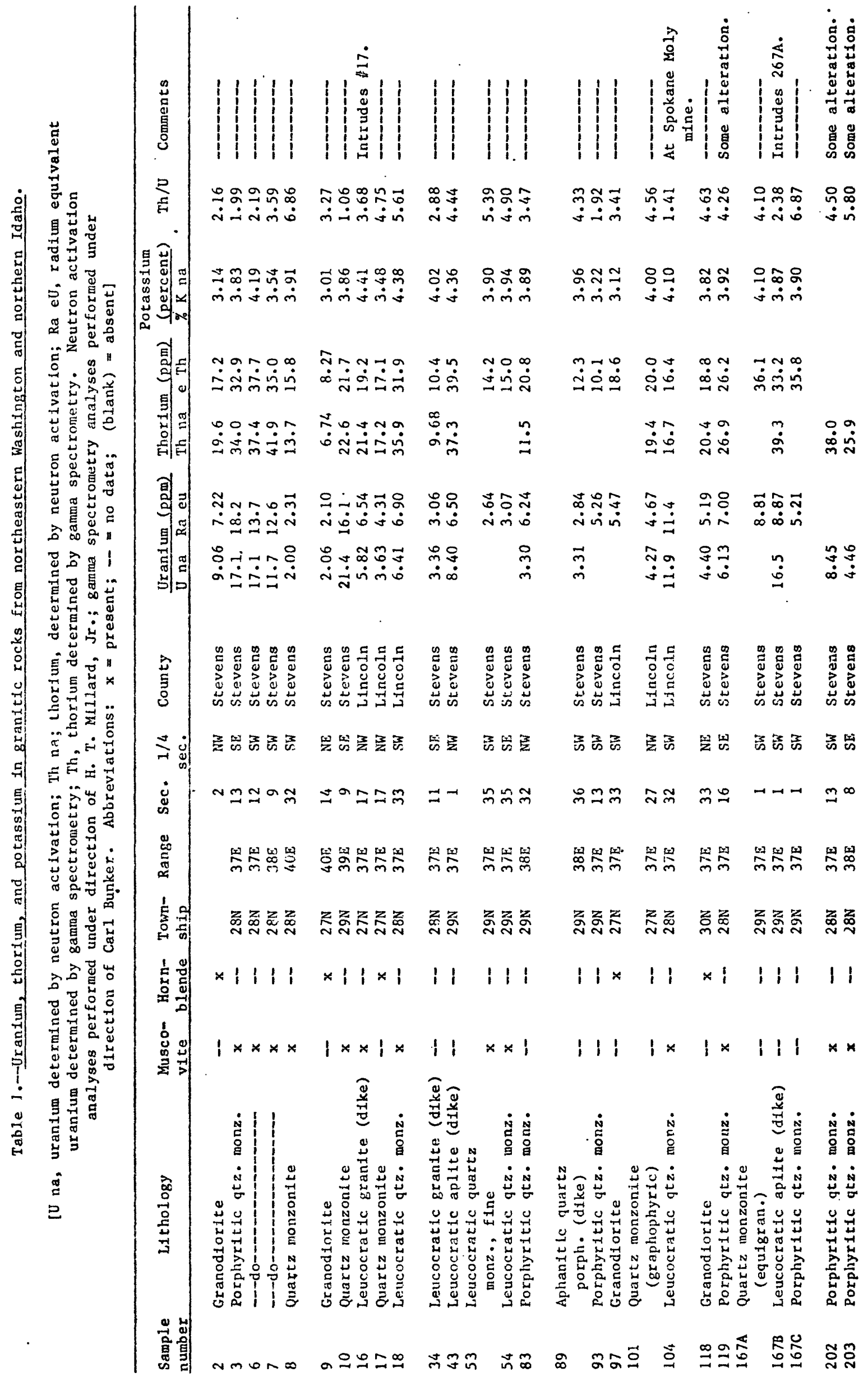




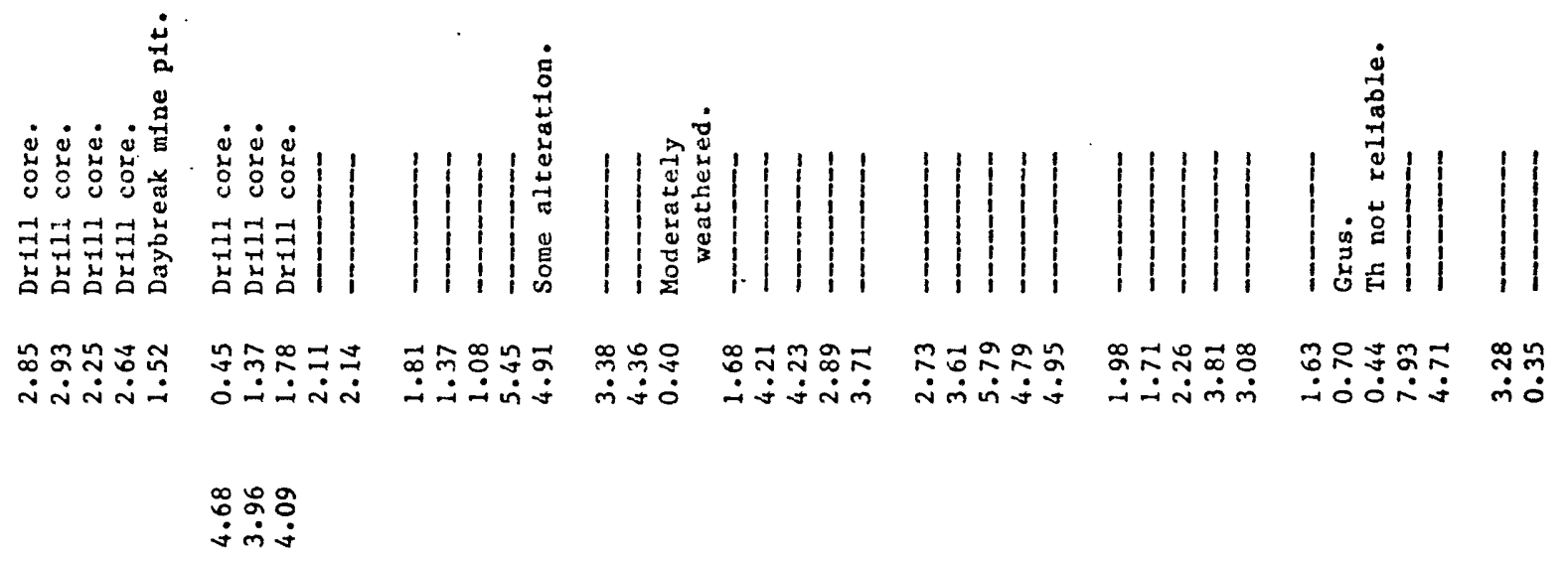

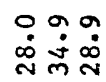

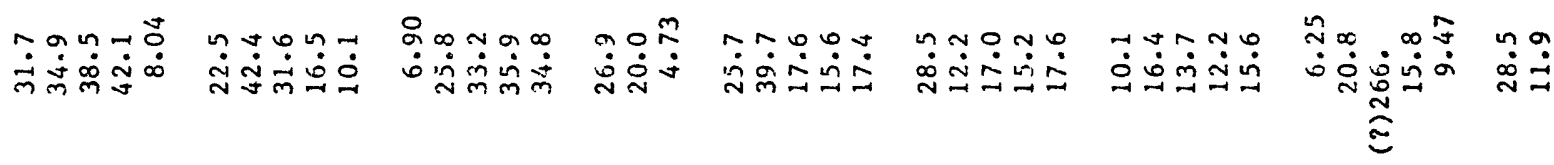

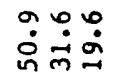

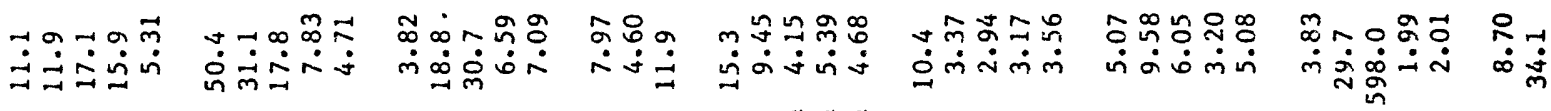

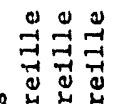

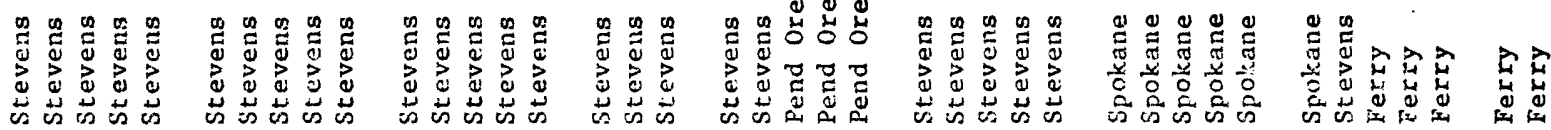

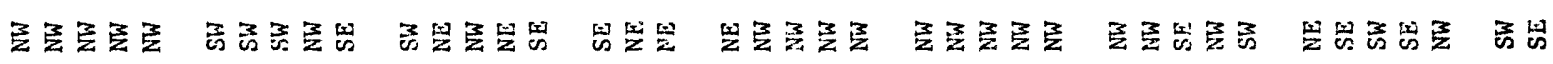

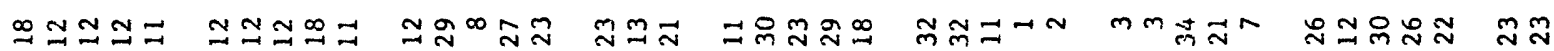

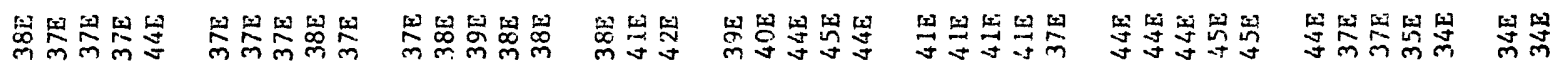

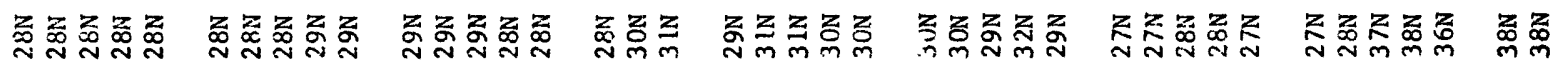

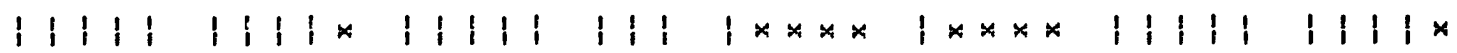

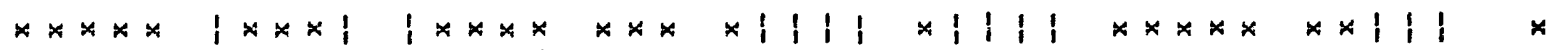

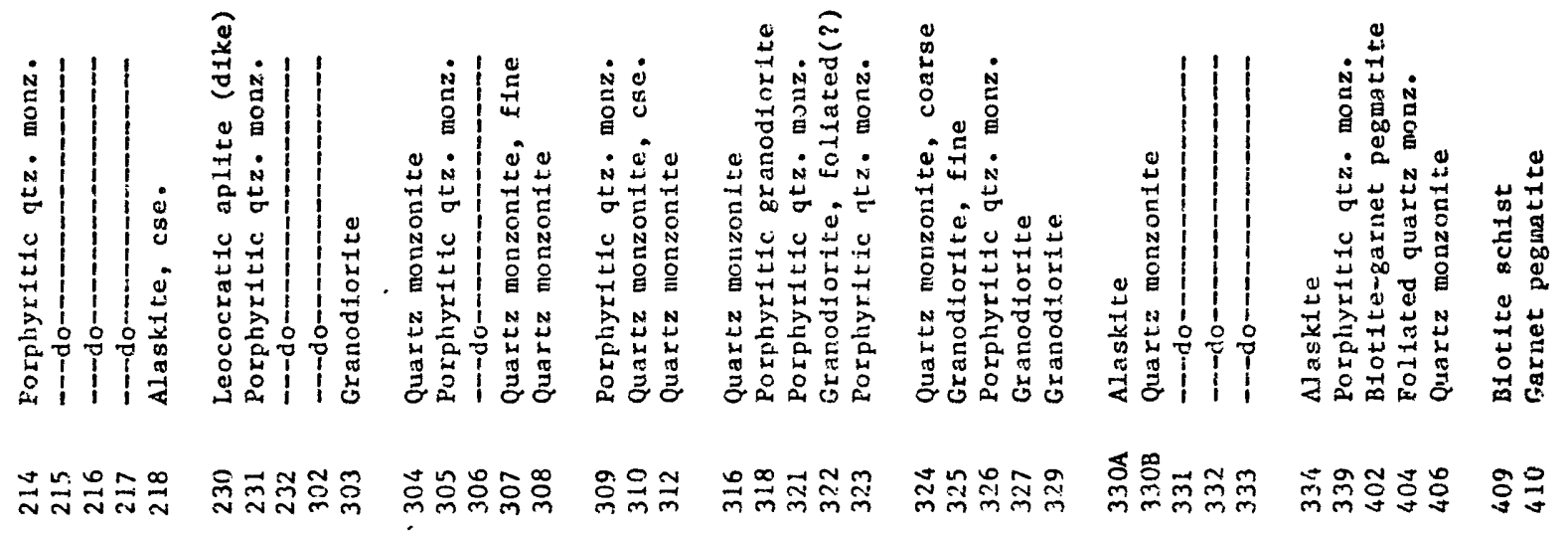



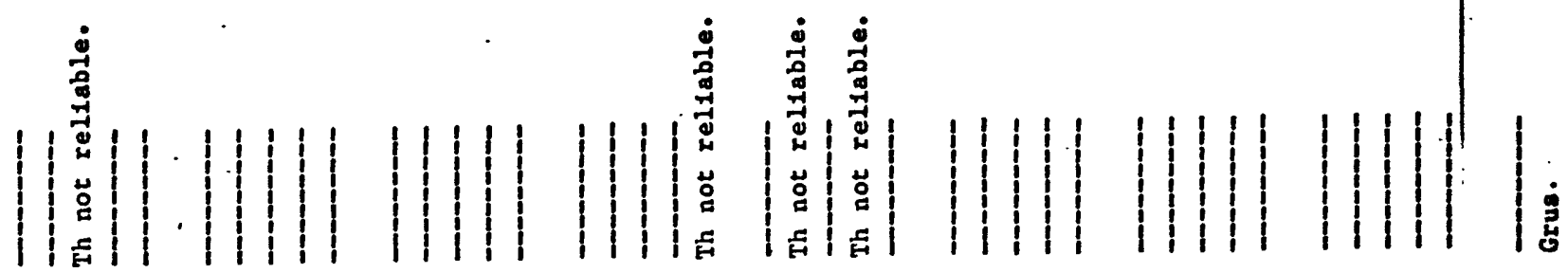

|

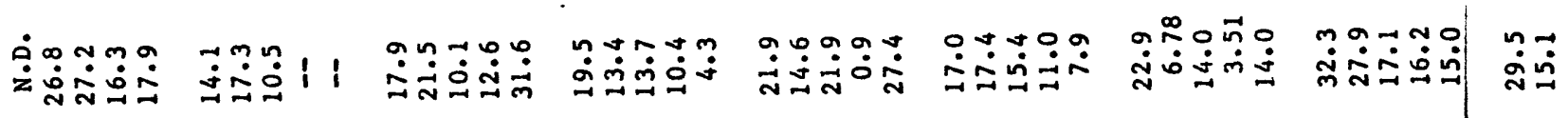

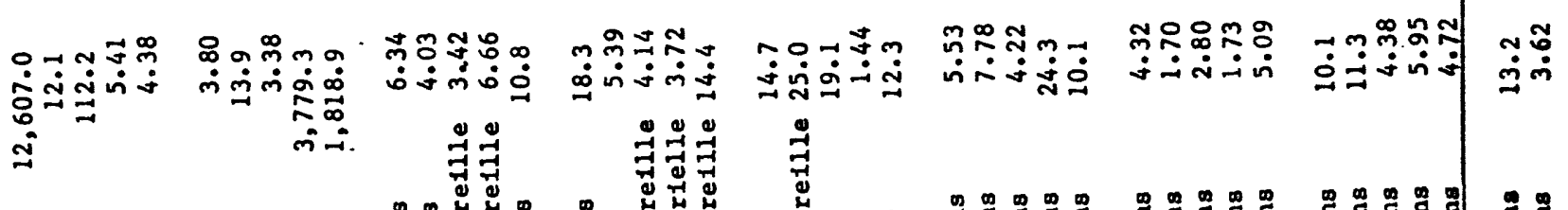

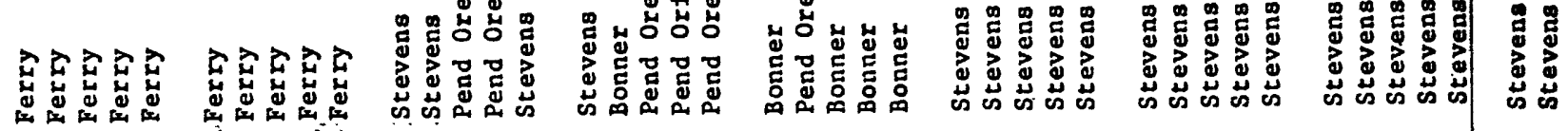

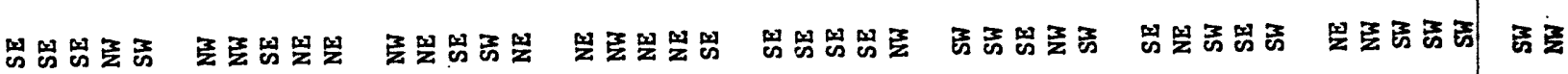

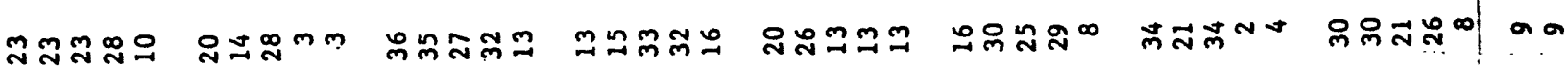

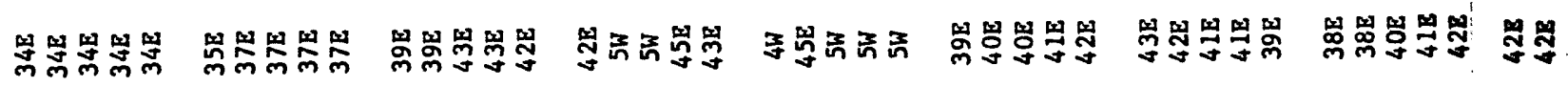

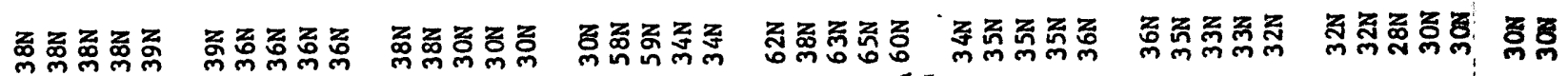

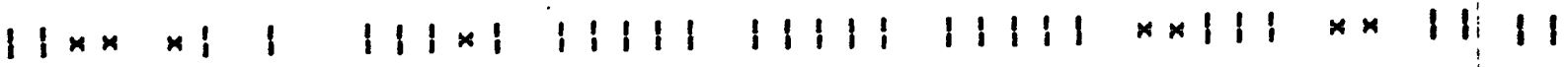

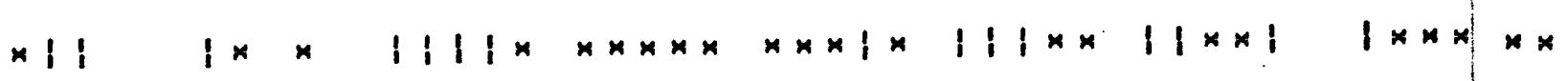

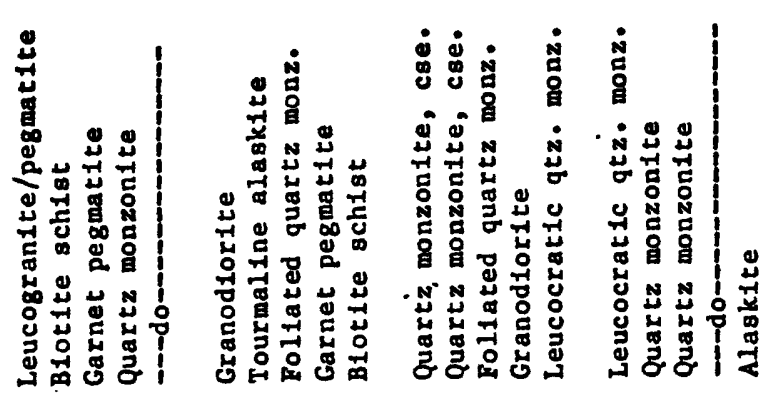

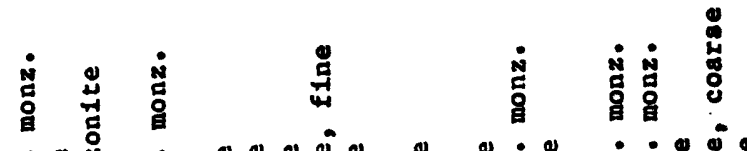

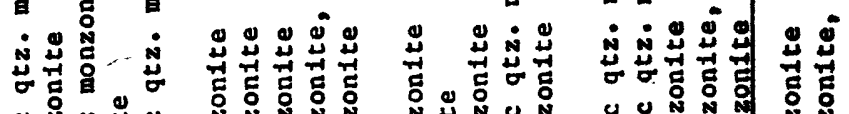

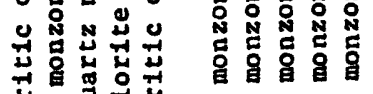

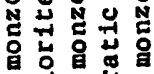

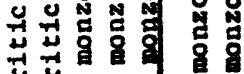

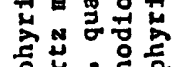

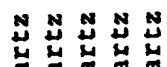

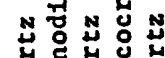

S

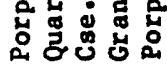

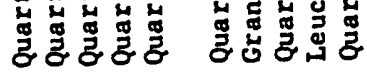

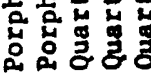

声

要要

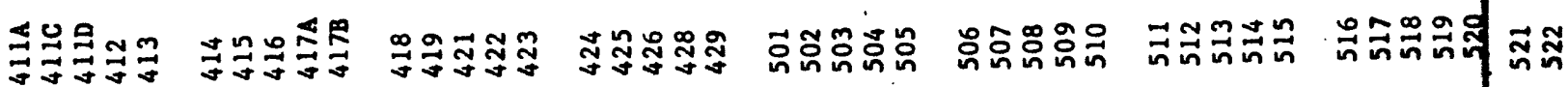




\section{PETROGRAPHY OF GRANITIC ROCKS}

Three general types of granitic-textured rocks are present in the study area: (1) Hornblende-bearing granodiorite and quartz monzonite containing about 10 to 30 percent mafic minerals; (2) biotite-muscovite quartz monzonite containing less than 15 percent (often less than 5 percent) mafics; and (3) biotite quartz monzonite, with no muscovite or hornblende, and total mafic content about 5 to 15 percent. Textures are often highly variable within and between plutons. Most are equigranular with medium grain size (1-5 mm), although many are coarse grained, and a few plutons are fine grained. Several plutons have porphyritic texture, generally fram potassium feldspar phenocrysts that can be as large as 30 $\mathrm{mm}$ across. These textures, generally visible in hand specimen, are summarized in table 2 for individual samples. For brevity the term biotite is not entered in the lithology column because nearly all samples contain biotite.

The plutonic rock classification used in this report is the same as that employed by F. K. Miller (Miller and Clark, 1975, p. 33-34) and others of the U.S. Geological Survey to avoid introduction of new lithologic names. Quartz monzonite by this classification is defined by modal mineralogy as a granitic-textured rock with more than 10 volume percent quartz and from 35 to 65 percent K-feldspar. Plagioclase composition in these rocks is generally greater than 15 percent anorthite. Many of the quartz monzonites by this modal definition would be termed granite by chemical definitions. The tem granitic is used in a broad sense to cover holocrystalline rocks with modal composition in the range granite to granodiorite. Muscovite-biotite quartz monzonites described here would generally fall in the class "two-mica granite" as used by French geologists.

The hornblende-bearing granitic suite seems to be spatially distinct from the biotite and biotite-muscovite suite as no gradation or zonation between suites is known within plutons. The hormblende-bearing suite also has distinct chemistry, being richer in iron, magnesium, calcium, and titanium than the other suites (F. K. Miller, oral commun., 1977). Sphene is an obvious accessory mineral in this suite and generally can be seen in hand specimen. No muscovite is known to occur in the hornblende-bearing 
suite, except for one sample (504) that contains secondary white mica replacing plagioclase.

Muscovite is a diagnostic constituent in more than half of the rocks collected. Muscovite content ranges from trace amounts to about 10 percent. Muscovite, when present, is generally at least approximately equal to biotite in abundance, and in many samples exceeds biotite in abundance. One pluton of muscovite quartz monzonite (Miller and Clark, 1975, p. 46-47) contains muscovite as its only mica. The muscovitebearing granitic rocks generally are very leucocratic; they often contain less than 5 percent mafic minerals. Muscovite occurs in several textural situations in these rocks: alone in the groundmass; within or adjacent to feldspars; adjacent to biotite; or enclosed in quartz. Some muscovite may be an alteration product of biotite or feldspar, although fine grained white mica (sericite) of deuteric origin is clearly distinguishable from muscovite crystals a millimeter or more in size. The isolated muscovite that exhibits no reaction relation to adjacent minerals seems to be a primary magmatic phase.

In a relatively small number of samples biotite is the only mafic mineral and no muscovite is present. Miller (1974a, 1974b) and Miller and Clark (1975) note that several plutons contain only biotite and no hornblende or muscovite. In other plutons muscovite or hornblende content is variable fram sample to sample. Most of the biotite-only plutons seem to be compositional variants of the two-mica suite.

There are very few published chemical analyses of granitic rocks from the study area, although studies are in progress by F. K. Miller and Felix Mutschler and his students. The hornblende suite seems to be in the calcalkaline-metaluminous chemical suite, and the muscovite suite is chemically alkalic-peraluminous. Averages and ranges for major oxides reported by Miller and Engles (1975, p. 518) are useful in showing chemical contrasts. For the hornblende suite the averages are as follows (in weight percent): $\mathrm{SiO}_{2}, 62-66$; total alkalis, 7 to $8 ; \mathrm{K}_{2} \mathrm{O} / \mathrm{Na}_{2} \mathrm{O}, 1.2$; total iron as $\mathrm{FeO}, 4 ; \mathrm{MgO}, 1.5$ to 2.0 ; $\mathrm{CaO}, 3.5$; and $\mathrm{TiO}_{2}, 0.6$. For the muscovite suite the averages are as follows (in weight percent): $\mathrm{SiO}_{2}, 66$ to 76 ; total alkalis, $6.6 ; \mathrm{K}_{2} \mathrm{O} / \mathrm{Na}_{2} \mathrm{O}, 0.9$; total iron as $\mathrm{FeO}, 2.0$; $\mathrm{MgO}$, 0.6 ; $\mathrm{CaO}, 2.4$; and $\mathrm{TiO}_{2}, 0.25$. Some chemical analyses and CIPW norms in 
table 2 demonstrate the aluminous, leucocratic character of the muscovite suite; normative corundum is characteristic of their chemistry.

The available chemical analyses suggest that rock chenistry, especially calcium, detemines accessory mineral character of these rocks as demonstrated by Lee and Dodge (1964) for granitic rocks elsewhere. The calcic hornblende suite contains sphene, allanite, and zircon as major accessory minerals, consistent with the observations of Lee and Dodge whereas the calcium-poor muscovite suite contains only traces of these accessories. This chemical-mineralogical relation is important for uranium because the accessory minerals in these rocks carry a large fraction of total-rock uranium, as will be shown in a later section, and mineralogical residence of uranium must determine the leachability of uranium by hydrothermal or supergene solutions. 
Table 2.--Chemical analyses and partial CIPW noms.

\begin{tabular}{|c|c|c|c|}
\hline $\begin{array}{l}\text { Oxide } \\
\text { (wt percent) }\end{array}$ & $\begin{array}{l}\text { Porphyritic quartz } \\
\text { monzonite of } \\
\text { Midnite mine }\end{array}$ & $\begin{array}{l}\text { Two-mica quartz } \\
\text { monzonite } \\
\text { average of } 4^{2}\end{array}$ & $\begin{array}{l}\text { Muscovite } \\
\text { quartz } \\
\text { monzonite }\end{array}$ \\
\hline $\mathrm{SiO}_{2}-\cdots$ & 73.3 & 74.2 & 75.1 \\
\hline $\mathrm{Al}_{2} \mathrm{O}_{3} \cdots$ & 14.5 & 14.1 & 14.0 \\
\hline $\mathrm{Fe}_{2} \mathrm{O}_{3}-\cdots$ & .9 & .66 & .22 \\
\hline $\mathrm{FeO}$ & .84 & .72 & .16 \\
\hline MgO_______ & .54 & .23 & .15 \\
\hline $\mathrm{CaO}$ & .14 & .73 & .53 \\
\hline $\mathrm{Na}_{2} \mathrm{O}$ & 3.2 & 3.1 & 4.1 \\
\hline $\mathrm{K}_{2} \mathrm{O}$ & 4.7 & 5.4 & 4.6 \\
\hline $\mathrm{H}_{2} \mathrm{O}^{+}-\cdots$ & .65 & .62 & .94 \\
\hline $\mathrm{TiO}_{2} \cdots$ & .24 & .12 & .04 \\
\hline $\mathrm{P}_{2} \mathrm{O}_{5} \cdots$ & .05 & .05 & - \\
\hline Mno-___-_-_ & .06 & .05 & .05 \\
\hline $\mathrm{CO}_{2}-\cdots$ & .05 & $\leq .05$ &. .05 \\
\hline Summary & 100.43 & 100.00 & 99.95 \\
\hline \multicolumn{4}{|l|}{ CIPW Norm } \\
\hline Quartz- - & 33.7 & 33.0 & 32.3 \\
\hline Corundum-- & 1.5 & 1.5 & 1.4 \\
\hline Magnetite- & 1.4 & 0.63 & .3 \\
\hline Hematite-- & 0 & 0.19 & 0 \\
\hline
\end{tabular}

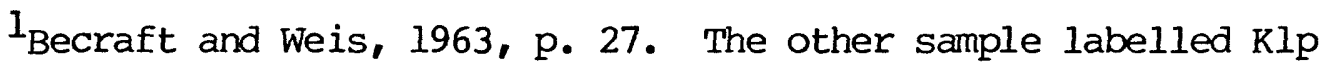
(7B-158) is from the same locality as my sample 17 (table 1); because it contains hornblende it is not considered to be the same as at the Midnite mine.

$2_{\text {Average of }} 4$ analyses from Becraft and Weis, 1963, p. 27. 3 Miller and Clark, 1975, p. 47. 
Results.-Chemical and gamma spectrometric analyses of uranium and thorium are shown in table 1 . For 98 samples of representative, seemingly unmineralized plutonic rocks the uranium content ranges from 1.44 to 31.1 parts per million (ppm) and for thorium the range is from 3.51 to 42.4 ppm. Sample 230, from a drill hole within the Midnite mine, contains 50.4 ppm $U$ and is suspected to contain at least some introduced uranium and will be excluded from further discussion of representative rocks. The thorium-to-uranium ratio ranges from 0.40 to 6.87 , and attention should be given to the 26 samples whose $T h / 0$ is less than 2.00 .

Mean values and standard deviations for the total plutonic rock sample population, excepting unreliable analyses or mineralized samples, is as follows:

\begin{tabular}{ll}
$\frac{\text { Mean }}{8.83} \mathrm{ppm}$ & \multicolumn{2}{c}{ Standard deviation } \\
Th- & $7.00 \mathrm{ppm}$ \\
Th/O-3 ppm & $9.96 \mathrm{ppm}$ \\
3.19 & 1.51
\end{tabular}

The mean value for uranium content, $8.83 \mathrm{ppm}$, is approximately twice the average, 4.0, uranium content of granitic batholiths in the western United States (Phair and Gottfried, 1964), and the mean thorium content, 20.3 ppm, is somewhat higher than the mean of $18.5 \mathrm{ppm}$ for western U.S. batholiths. The significance of these mean values for the Washington and Idaho rocks is, of course, subject to question because the sampling program emphasized radioactive rocks, especially the Cretaceous(?) porphyritic quartz-monzonite pluton within $10 \mathrm{~km}$ of the Midnite mine. However, the data in table 1 do support the concept that northeastern Washington and northern Idaho is a uranium province, as proposed by Castor and others (1978).

Comparison of analytical results of this study with those of Castor and others (1978), and previous studies summarized in Castor and others (1978), is not straightforward because the other studies relied on gamma spectrometric and fluorometric analyses, whereas most data in this study came from the delayed neutron technique which measures uranium directly from whole rock powders and hence is not subject to error because of problems with disequilibrium or incomplete digestion. The best comparison 
I can make is on results for sample pairs which, according to map location, probably came from the same road cut, or were collected no more than 1 mile apart in the same pluton. Twenty-five sample pairs meet these standards, and for them the results are very similar. Correlation coefficients for the uranium and thorium analyses are +0.750 and +0.823 , respectively, which are significant at the 99.9 percent confidence level. Although linear correlation statistics suggest probable systematic analytical differences, for purposes of reconnaissance and exploration studies the discrepancies are not serious and are well within the range of geologic variability.

Rock associations. - The uranium and thorium data are more easily comprehended when considered according to two major rock suites; the hornblende-bearing and the muscovite-bearing granitic rocks. Statistics for these rock types are shown in table 3. These statistics point out that, on the average, the muscovite-bearing suite contains more than twice as much uranium as the hornblende-bearing suite; and the thorium content is also much higher in the muscovite suite. The uranium and thorium contents and $T h / \mathrm{U}$ of the muscovite suite are significantly different from those of the hornblende suite at the 99 percent confidence level. Statistics reveal that the mean uranium and thorium contents of 19 samples of porphyritic quartz monzonite of the Midnite mine, are significantly higher (at 99 percent confidence level) than the muscovite-suite in general; the mean $\mathrm{Th} / \mathrm{U}$ ratios are statistically indistinguishable. The statistics for the porphyritic quartz-monzonite group of samples consider only the muscovite-bearing samples; inclusion of data for five samples that do not contain muscovite lowers the means to $12.8 \mathrm{ppm} \mathrm{U}$ and $30.2 \mathrm{ppm}$ Th respectively, and raises the mean $\mathrm{Th} / \mathrm{U}$ to 2.96 . It should be noted that the samples of porphyritic quartz monzonite are representative and none were judged to be hydrothemally altered or mineralized; the samples from drill holes are more than $200 \mathrm{~m}$ from known ore.

The porphyritic quartz monzonite of the Midnite mine contains nearly four times as much uranium as quartz monzonite worldwide and about twice the normal amount of thorium. Selection of the 14 freshest samples (very little clay in plagioclase, chlorite in biotite, or pyrite after magnetite) raises the mean uranium and thorium contents to 17.0 and 34.7 ppm, respectively, and lowers the standard deviations. 


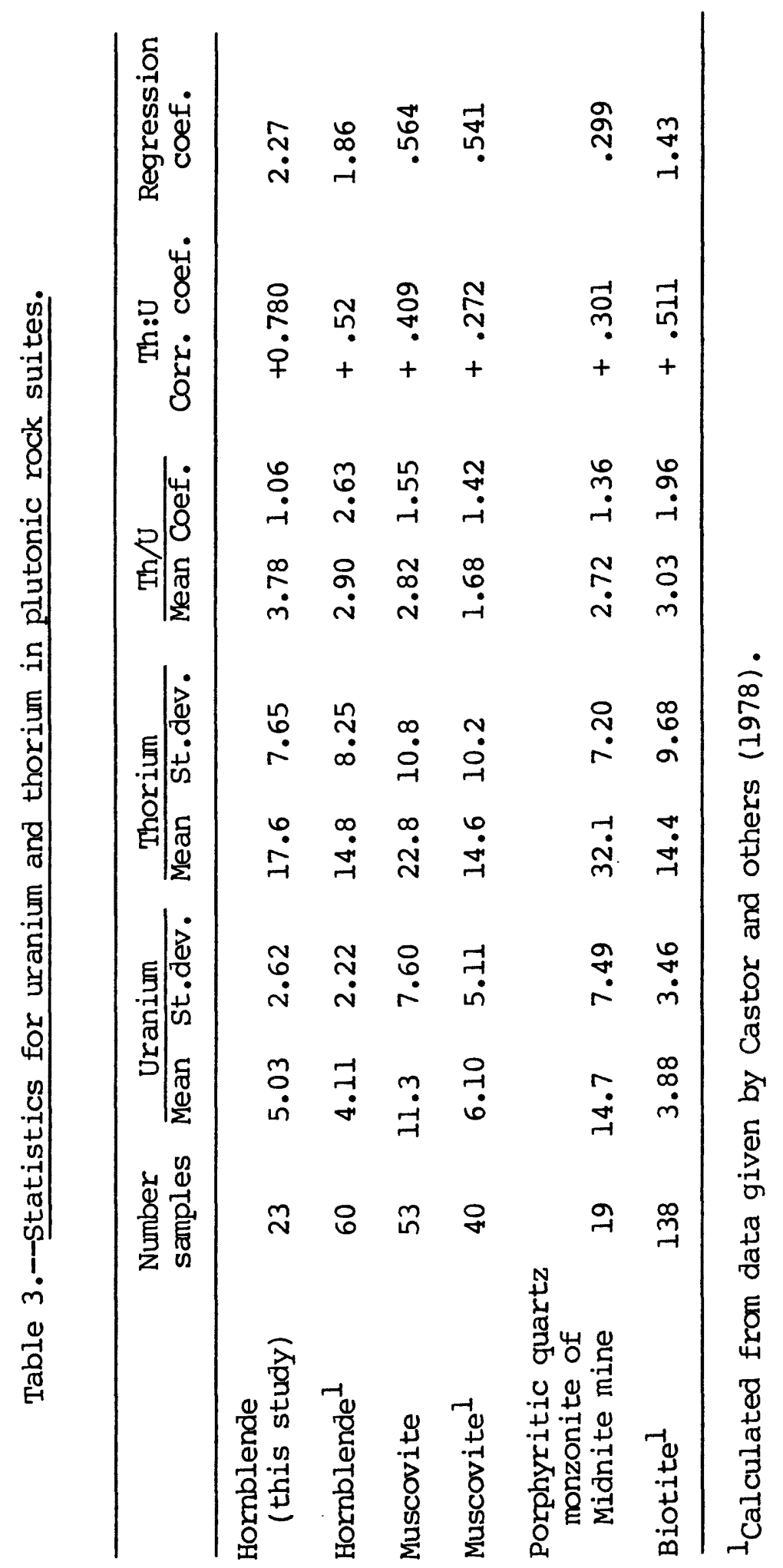


Thorium content and variation.--The thorium contents of the granitic rocks span the range 3.51 to $42.4 \mathrm{ppm}$ and there is fairly even distribution of values within this broad range. As mentioned before, the mean thorium content of the muscovite suite is significantly higher than that of the hornblende suite, and the mean thorium content of the porphyritic quartz monzonite of the Midnite mine is particularly high. Because the range in rock compositions is not particularly great, especially for the muscovite suite, I do not favor attributing the variation in thorium (or uranium) content solely to magmatic fractionation, as is commonly advocated. Several plutons are characterized by relatively low thorium contents, less than about $15 \mathrm{ppm}$, and this feature may be as instructive as the occurrence of thorium enriched rocks. Thorium; as opposed to uranium, is generally considered to be relatively immobile in the weathering environment, and thus variations in thorium can probably be related to magmatic processes with more confidence than uranium variations. I speculate that thorium variation, as observed here, might be related to one or more of the following factors:

(1) Magmatic fractionation--Produces enrichment in later, more alkalic differentiates (probably not important as only small compositional range is observed).

(2) Partial melting in anatexis--Could result in enrichment or depletion in thorium depending upon the Th-rich phases in source rocks and whether they melt easily or are refractory.

(3) Source rock composition-The rocks with relatively low thorium content probably are anatectic melts derived from thorium-poor sedimentary rocks.

(4) Hydrothermal transfer--Possible but less likely for thorium than for uranium. Hydrothermal enrichment of thorium relative to uranium does not seem probable, but the reverse could well happen.

Thorium:uranium ratio and correlation.--The wide variation in $T h / \mathrm{N}$, from 0.40 to 6.87 can, of course, be caused by variation in either element. Rocks with low Th/ $\mathrm{U}$ are of interest because they are suspected to contain a higher proportion of labile uranium as discussed ahead. Twenty-six plutonic rocks (table 1 ) have Th/U less than 2.00; several of 
these have questionable thorium analyses, but nonetheless probably are reliably in the less than 2.00 category. It is important to note that only two samples of the 26 contain hornblende, and 21 are muscovite bearing.

Several researchers have suggested that thorium-rich rocks are a good guide to rocks enriched in uranium (Rogers and Adams, 1969; Stuckless and Ferreira, 1976). This hypothesis presumes that uranium and thorium correlate positively in the rock suite of interest. Is this a good criterion for the plutonic rocks of Washington and Idaho? Statistics for uranium and thorium in rocks from this study (table 2, fig. 1) suggest that behavior of these elements varies with rock suite and that thorium content may not be a good criterion for selecting uranium-rich rocks in the muscovite suite. In all rock suites uranium and thorium correlate positively (table 2), as is normally observed. The correlation is significant at the 99 percent confidence level for all suites except the porphyritic quartz monzonite of the Midnite mine. The linear regression test yields other information, for example uranium and thorium covariation is different in the hornblende suite as compared with the muscovite suite. In the hornblende suite the regression coefficient (slope term of the least squares best fit line) of thorium on uranium is 2.27 for my data and 1.86 for data from Castor and others (1978), whereas the regression coefficient is $0.564,0.541$, and 0.229 for three sets of muscovite-bearing samples. These coefficients mean that as uranium and thorium contents increase, thorium in the hornblende suite increases about twice as much as uranium, whereas in the muscovite-bearing rocks thorium increases only half as much as uranium. The regression coefficient of $\dot{1} .43$ calculated for the biotite suite of rocks of Castor and others (1978) is intemediate, and possibly reflects mixing of data that I would have assigned to the hornblende or muscovite suite, or possibly reflects a true intemediate type of petrochemistry. The contrasts in U-Th covariation in the hornblende and muscovite suites suggest that different magmatic processes, or possibly different mineralogies, affect uranium and thorium concentration.

Thorium does not seem to be as reliable a guide to uranium in these plutonic rocks as it does in rock suites elsewhere. It appears that the greatest thorium enrichment occurs in alkalic and calk-alkalic rocks 

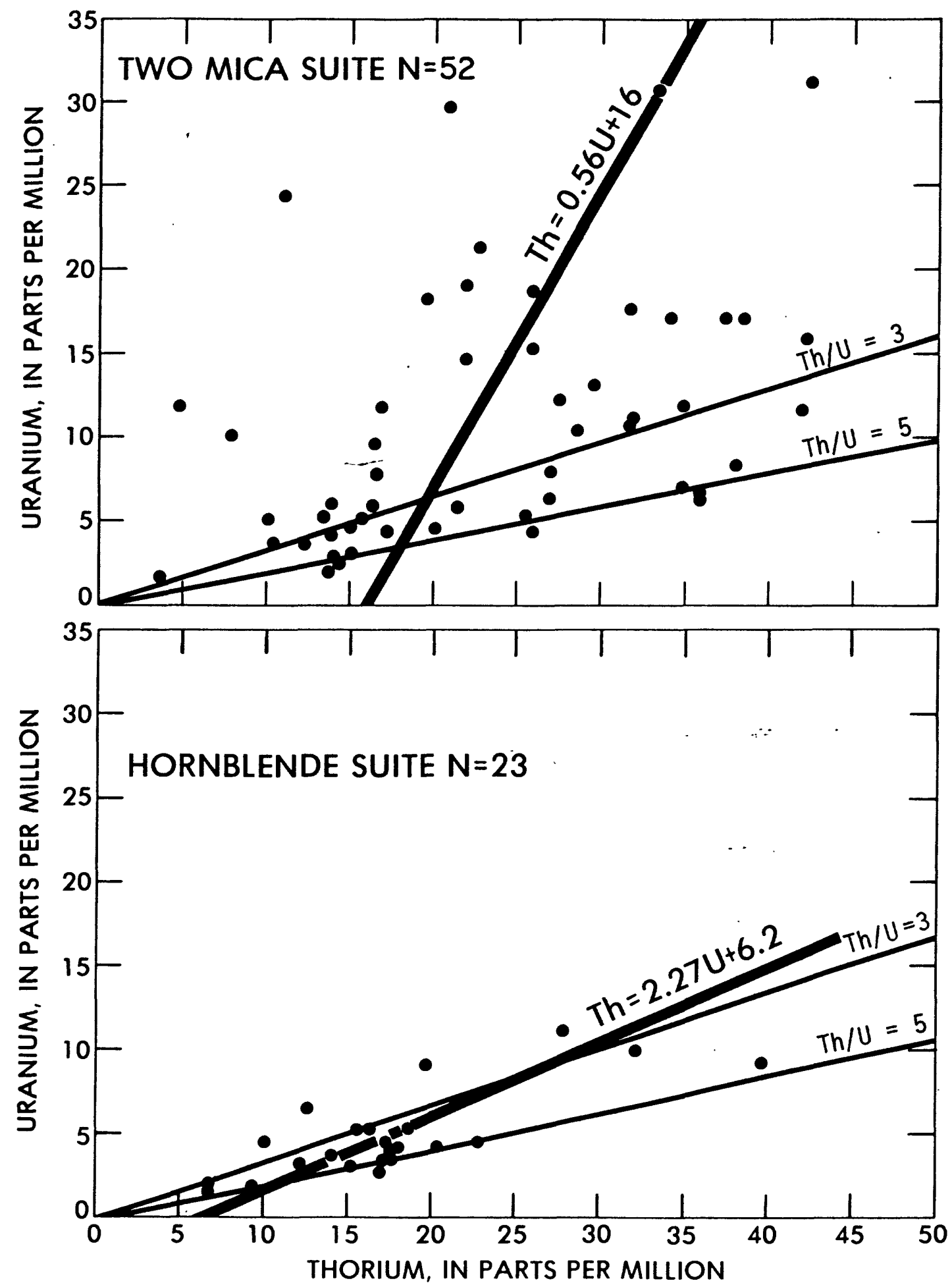

Fig. 1.-- Variation of uranium and thorium in two granitic rock suites. World normal thorium:uranium ratios are in the range of 3 to 5 . 
around the world, and for these suites the thorium criteria using a $50 \mathrm{ppm}$ base level of thorium for favorable uranium-rich rocks is very useful (Stuckless and Ferreira, 1976). However, in peraluminous rocks of this study area, as well as in New Hampshire and France, there is not as much enrichment in thorium in uraniferous plutons and the $50 \mathrm{ppm}$ thorium criterion would miss the favorable uraniferous plutons.

Plutonic rocks of New Hampshire display mineralogical and radioelement variation very similar to that described for the plutons in this study area. A particularly interesting pluton is the peraluminous two-mica granite of Lake Sunapee that contains an average of $15 \mathrm{ppm}$ uranium but only 8 ppm thorium (E. I. Boudette, written commun., 1978). The nearby Conway Granite, an alkalic granite, is famous (Richardson, 1964 ) for its enrichment in thorium (average $59 \mathrm{ppm}$ ) as well as uranium (13 ppm; E. I. Boudette, written commun., 1978).

Two-mica granites of the Massif Centrale, France, which contain important vein deposits of uranium, have been studied in detail (Barbier and Ranchin, 1969; Cuney, 1978; Leroy, 1978) and have been shown to be more enriched in uranium than in thorium (relative to crustal averages). Several plutons have Th:U less than 1.5, and some facies contain more than 20 ppm uranium. Paricularly favorable granitic rocks, called "fertile"l by the French, contain more than $10 \mathrm{ppm}$ uranium and the uranium is chiefly in minerals such as uraninite or biotite. Granitic rocks that are rich in thorium and carry uranium in accessory minerals such as zircon, allanite, or thorite, are not considered to be fertile (Bernard Poty, oral commun., 1978).

Any study of uranium and thorium concentrations and Th:U ratios must consider the effects of the differing geochemical mobility of the two elements, particularly the well known leachability of uranium in the near-

$I_{\text {The term }}$ "granite fertile" was introduced by Moreau (Moreau and others, 1965) to describe granitic rocks containing abnomal amounts of uranium in leachable form. Presence of uranium in minute crystals of uraninite is a feature of the most fertile granites (Barbier and Ranchin, 1969; Cuney, 1978). 
surface environment (Barbier and Ranchin, 1969; Stuckless and others, 1977a). Ideally, samples from diamond drill core several hundred or more meters deep should be used, but for a reconnaissance program this is not practical. There are two arguments that can be made regarding the reliability of samples used in this study. (1) There is evidence for uranium leaching on the basis of radiometric profiles from weathered to unweathered rocks in road cuts and canyons. In some places radioactivity is reduced by more than 50 percent in the weathered zone. However, in other areas grus contains virtually as much uranium (by chemical determination) as unweathered rock nearby, indicating that uranium is not always removed by weathering processes. Fission-track maps of a few weathered samples show that uranium has moved into cracks and grain boundaries, but total content has not been changed appreciably (less than $\pm_{10}$ percent). (2) Samples from drill holes at depths of about $200 \mathrm{~m}$ do not contain appreciably more uranium than fresh samples from roadcuts. The way to obtain fresh samples with little uranium loss seems to be collecting them from cuts into relatively unfractured rock and taking the sample more than $0.3 \mathrm{~m}$ from joints. Such samples are very coherent, and feldspars and biotite are crisp and lustrous with no megascopic indications of alteration to clay minerals.

Under appropriate weathering or alteration conditions, I believe that uranium in the muscovite-bearing rocks in particular would be leachable. Evidence for this is in some natural weathering profiles, mentioned previously. Also, consider that mineralogic residence of uranium is in phases such as magnetite and biotite that are more susceptible to alteration than accessory minerals such as zircon, allanite, and thorite. In addition, an average of 57 percent of uranium in muscovite-bearing granitic rocks is leachable in $4 \mathrm{~N} \mathrm{HNO}_{3}$ (Castor and others, 1977). However, with careful sampling of only the least fractured and weathered rocks, I believe that samples can be collected containing most all their primary (magmatic) uranium. Data for uranium concentration and Th:U ratio seem to be reliable on such samples. 


\section{RESIDENCE OF URANIUM IN GRANITIC ROCKS}

The fission-track map technique was employed to determine the distribution of uranium in 34 samples of granitic rocks. Four distinctive mineralogic and petrologic associations were noted: (1) Correspondence of very high track densities with magnetite grains in the muscovite suite; (2) small but very high density clusters of tracks that have no apparent correlation with any rock-forming minerals in the muscovite suite; (3) correspondence of moderate to high track densities with heavy minerals such as sphene, zircon, and allanite, chiefly in the hornblende suite; and (4) correspondence of high track densities with secondary iron oxides in weathered samples.

Fission-track maps made of samples from the muscovite suite demonstrate that high track densities (high uranium concentrations) often correlate with magnetite grains (figs. 2 and 3 ). In fresh rocks the fission-track pattern is virtually identical with the cross section of magnetite crystals exposed in the thin section. No textures suggestive of exsolution have been seen, and only rarely does the track pattern outline magnetite grains. Although it is difficult to be certain whether magnetite grains reflect magmatic crystallization or subsolidus recrystallization, the coincidence of tracks and magnetite suggests that uranium entered the magnetite lattice during its crystallization and was not expelled during subsequent cooling or post-magmatic hydrothermal processes. The other important feature of fission-track maps of muscovite-bearing samples is track clusters about 10 microns across (fig. 2) that cannot be correlated with any discrete mineral of this size. These "hot spots" match up with interior portions of orthoclase or quartz grains, with grain boundaries, and in some instances with interior portions of muscovite grains. The high track density and small size of the "hot" areas are suggestive of a small but uranium-rich mineral such as uraninite. More detailed studies, possibly employing polished thin sections or mineral separates, might resolve this problem. Fresh samples fram the muscovite suite showed only scattered, low density of tracks associated with muscovite, and feldspar and moderate track density coincident with biotite (fig. $3 \mathrm{~A}$ ). No track association with grain boundaries was noted except in weathered samples. Refractory minerals such as zircon and sphene produce high track densities. These minerals 


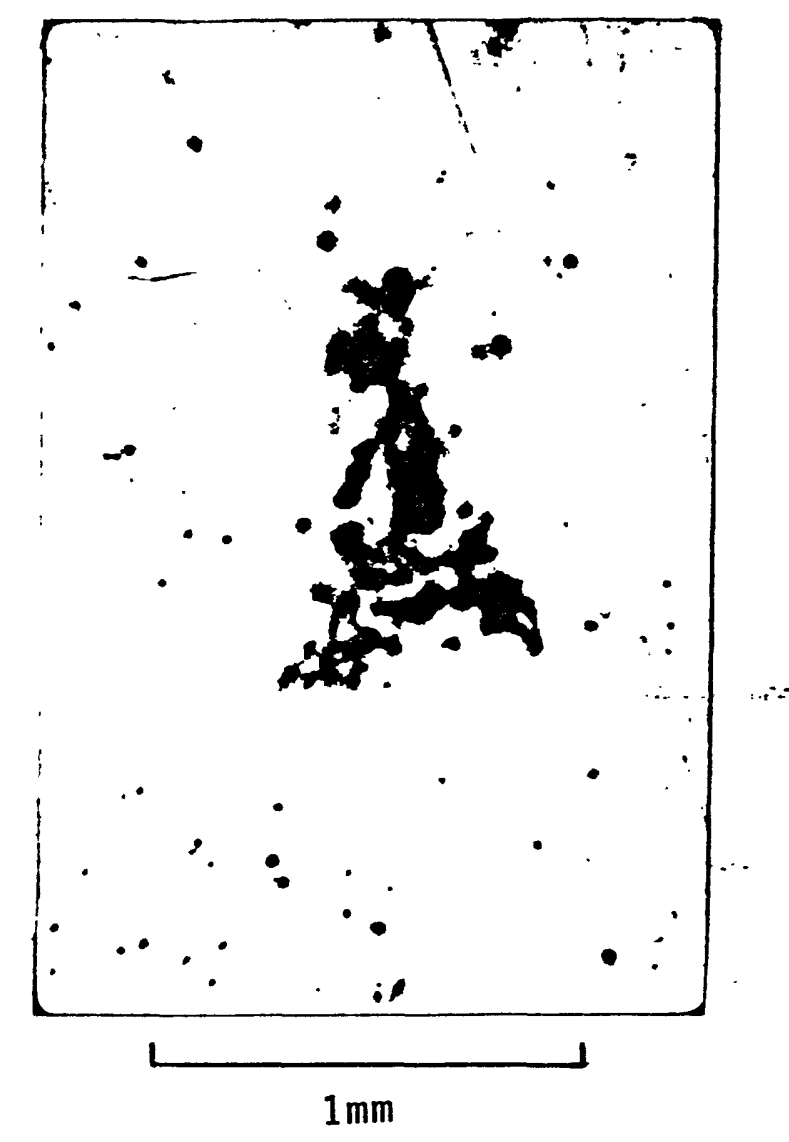

Figure 2.-- Photograph of fission-tracks produced by uranium in magnetite. Sample 202. 

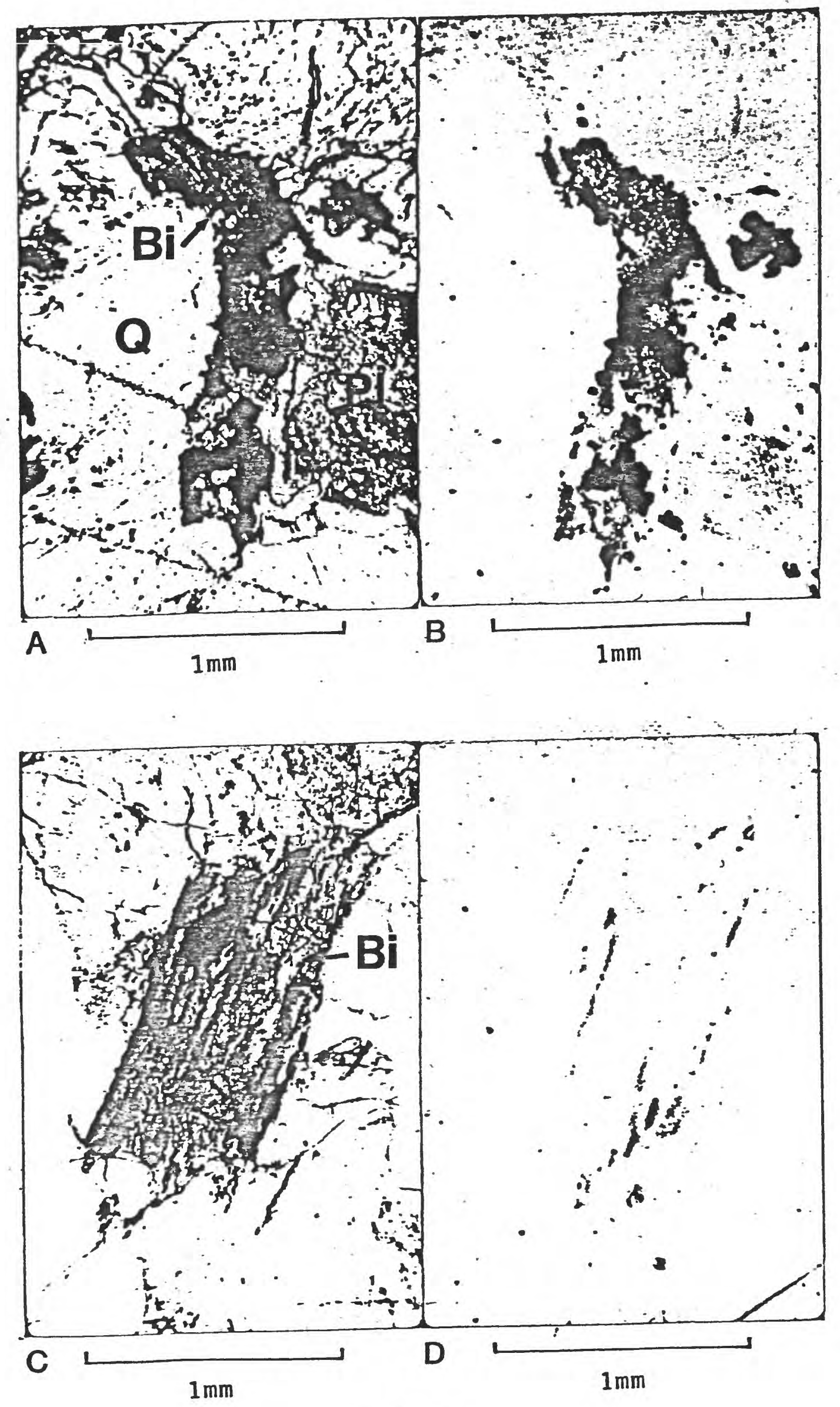

Fig. 3 . 
Figure 3.--Photographs of thin sections and corresponding fission-track maps showing the distribution of uranium. Bar scale in all photos is $1 \mathrm{~mm}$.

A.--Sample 309, porphyritic quartz monzonite of the Midnite mine in transmitted light. Bi, biotite; Q, quartz; Kf, K-feldspar phenocryst; pl, plagioclase.

B.-Fission-tracks of same area of sample as in A. Dark areas produced by high track density coincide with magnetite; moderate track density coincides with biotite grain.

C.-Sample 429, oxidized biotite containing iron oxides in leucogranite of Phillips Lake Granodiorite.

D. Fission-tracks of same area of sample as in C, showing moderate concentration of uranium in secondary iron oxides. 
are rather rare in the muscovite suite and do not seem to carry much of the total rock uranium.

In the hornblende suite, highest track densities correspond to crystals of sphene (fig. 4B), zircon, and allanite (fig. 4D). Only scattered tracks are associated with other minerals in this suite. It seems that a high proportion of total-rock uranium is carried by accessory minerals in the hornblende suite. A similar association was noted by Simpson and others (1977) in some granitic rocks from England.

Uranium in weathered granitic rocks appears to have migrated from rock-forming minerals into secondary iron oxides, as shown by high track densities associated with the iron oxides (fig. 3D). This association has been noted elsewhere in altered rocks (e.g. Simpson and others, 1977; Stuckless and others, 1977a; Nash, 1977b). The incorporation of uranium into the iron oxides during weathering appears to retain most of the original rock uranium, at least in some localities, but the fission-track maps show conclusively that the uranium has migrated.

These qualitative textural studies demonstrate two important relations. Firstly, much uranium in the muscovite-bearing rocks is in what seem to be labile sites such as magnetite and possibly uraninite, whereas in the hornblende suite much uranium is held in refractory accessory minerals. This further emphasizes the difference between the hornblende and muscovite suite, rocks of the muscovite suite are considered more likely to be fertile because not only is their mean uranium content higher, but also more of the uranium is in labile suites. The second useful finding is that the fission-track technique can be of use in evaluating uranium leaching or mobilization. A combination of uranium determinations and fission-track maps from multiple sample localities in a pluton should permit fairly confident, yet inexpensive, evaluation of primary uranium content, whether leaching has occurred, or if uranium has been introduced. 

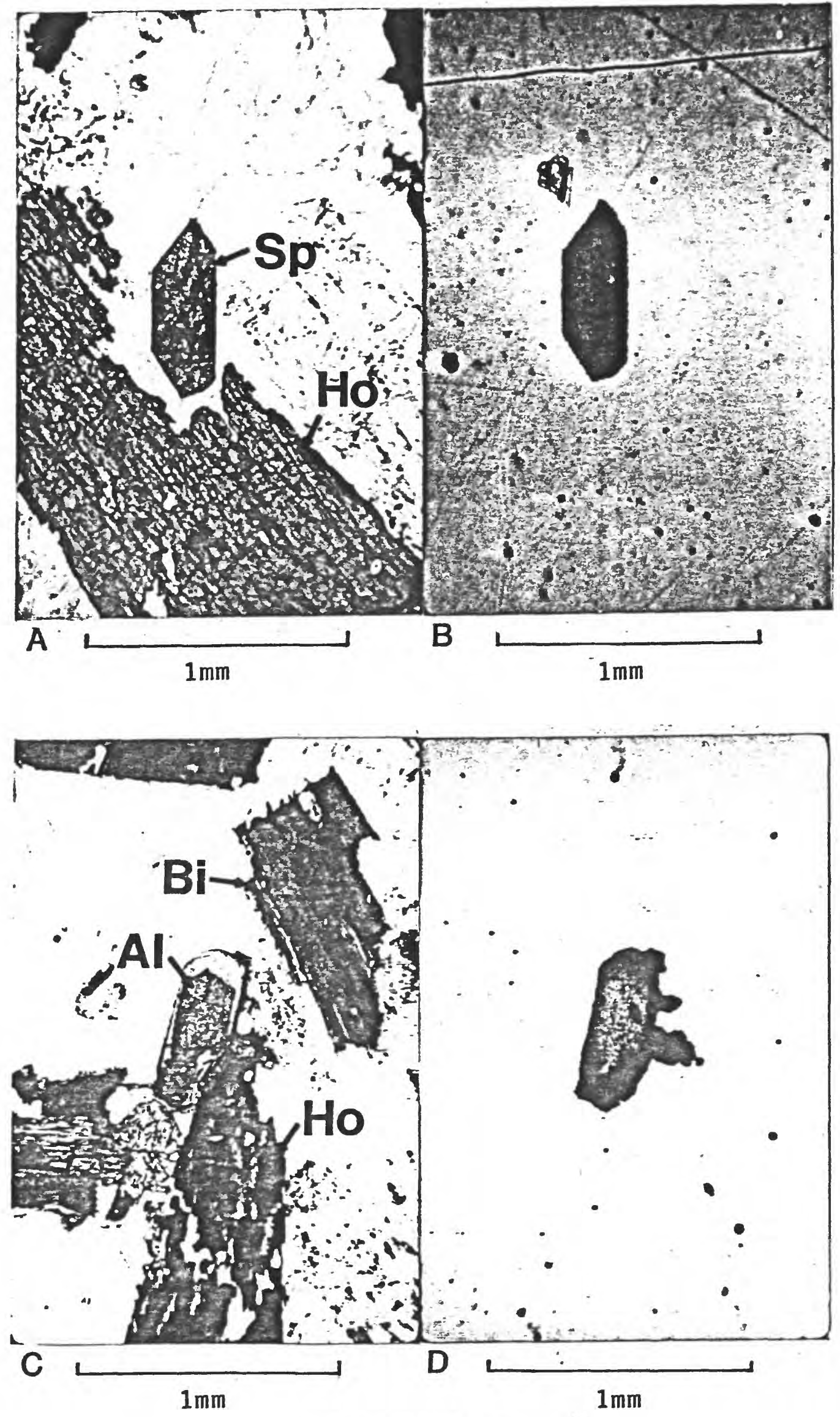

Figure 4.-- 
Figure 4.--Photographs of thin sections and fission-track maps of hornblendebearing rocks. Bar scale is $1 \mathrm{~mm}$ long.

A.--Sample 422, Fan Lake hornblende granodiorite in transmitted light. Sp, sphene; and Ho, hormblende.

B.-Fission-track map of same area of sample A. High track density coincides with sphene crystal. Major rock-forming minerals contain very low concentrations of uranium ( $<10 \mathrm{ppm}$ ).

C.--Sample 422, hornblende-rich Fan Lake Granodiorite in transmitted light. Al, allanite; Bi, biotite; and Ho, hornblende.

D.-Fission tracks of same area of sample C. Highest track density is coincident with outer yellow zone of allanite, moderate track density in brown core of allanite. 
The fission-track studies of these rocks, and of uraniferous granites fram southeastern Missouri (Nash, 1977b) suggest the possibility that fertile granitoid rocks could be tested by analysis of magnetite fractions for uranium. The hypothesis is that some fertile plutons contain uraniumrich magnetite, whereas non-fertile plutons, such as the hornblende suite, contain uranium-poor magnetite. Analyses (F. N. Ward, written commun., 1977) of seven magnetite concentrates fram muscovite-bearing granitic rocks show most are quite rich in uranium as shown in the following table.

\begin{tabular}{ccc}
\hline $\begin{array}{c}\text { Sample } \\
\text { no }\end{array}$ & $\begin{array}{c}\text { Uranium in } \\
\text { magnetite (ppm) }\end{array}$ & $\begin{array}{c}\text { Uranium in rock } \\
\text { (ppm) }\end{array}$ \\
\hline $202-$ & 24.3 & 8.45 \\
203 & 6.2 & 4.46 \\
$214-$ & 18.4 & 11.1 \\
215 & 180 & 11.9 \\
216 & 43.8 & 17.1 \\
$217-$ & 150 & 15.9 \\
$142-$ & 50.6 & 14.7 \\
\hline
\end{tabular}

Results obtained by N. J. Lehman (oral commun., 1977) confirm the high uranium content of magnetites from muscovite-bearing granitic rocks of Stevens County, and concentrations less than $10 \mathrm{ppm}$ were found in magnetite from the hornblende suite. The variation in uranium content of magnetites from the muscovite suite was not expected from the fissiontrack studies as all magnetites within and between muscovitic samples seemed to produce generally similar track densities. Possibly uraniumrich grains (such as uraninites?) were variably concentrated with, or separated fram, the magnetite fraction during physical mineral concentration. Sample 203 shows mineralogical evidence of weathering, and that process may have removed uranium from magnetite in that sample, and also reduced total-rock uranium.

${ }^{1}$ Sample from southern Missouri (Nash, 1977b). 
URANIUM AND THORIUM IN MIGMATITIC ROCKS

Nine samples of metamorphic rock from the migmatite terrane of the Kettle River Range, Ferry county, were collected for petrologic and chemical study (table 1). These samples are considered to be mineralized; as small composite samples consisting of several chunks with total weight about $1 \mathrm{~kg}$, however, they do not represent the grade of mineralized zones. Barlow (1958) reports assays of 0.01 to 0.21 percent $\mathrm{eU}_{3} \mathrm{O}_{8}$ over 1 to $5 \mathrm{ft}$ $(0.3-1.5 \mathrm{~m})$ widths and typical grades of 0.04 to 0.09 percent $\mathrm{eU}_{3} \mathrm{O}_{8}$ across pit faces and in stockpiles. Chemical assays of uranium generally are slightly in excess of radiometric (Barlow, 1958).

Uraniferous rocks in the Kettle River Range that I examined are biotite-amphibole schist, leucocratic "pegmatite," and in a few places, quartzite and granite gneiss. In the deposits I examined "pegmatite" was the preferred host, although elsewhere in the area biotite schist or calcsilicate skarn are favored. The "pegmatites" are discontinuous lenses 1 to $5 \mathrm{~m}$ thick and less than $100 \mathrm{~m}$ long, have medium to very coarse grain size, and are composed primarily of white orthoclase, clear to smoky quartz, pink garnet, and variable amounts of tourmal ine, muscovite, allanite, and other trace constituents (table 4 ).

Uranium contents of biotite schists and leucocratic pegmatites are highly variable (table 1; Barlow, 1958). Residence of uranium seems to be complex in detail. Some is carried in smail euhedral uraninite grains, or as secondary uranium minerals such as uranophane and autunite. Fissiontrack maps of samples 402,415 , and $417 \mathrm{a}$ indicate that uranium contents of biotite, garnet, and tourmaline, are very low $(<10 \mathrm{ppm})$. The fissiontrack patterns of these rocks indicate that most uranium occurs in thin cracks as an unidentifiable mineral, and in zircon; no uranium minerals were detected in the small area of the thin sections. Barlow (1958) reports that most samples of the uraniferous "pegmatite" and schist are refractory and require carbonate leaching under strongly oxidizing conditions for good recovery. The reasons for this refractory behavior are not evident from our brief mineralogical studies. 
Table 4.--Mineralogy of uraniferous migmatites

[Minerals detemined in mineral separates by Katrin Zarinski using optical and X-ray methods. Abbreviations: All, allanite; Alm, almandite garnet; Apat, apatite; Bio, biotite; Col, columbitetantalite; Ilm, ilmenite; Mag, magnetite; Moly, molybdenite; Mon, monazite; Py, pyrite; Rut, rutile; Sill, sillimanite; Tour, tourmaline (dravite); Uph, uranophane; and Uran, uraninite; leaders (- $)$ indicate no data.]

\begin{tabular}{|c|c|c|c|c|}
\hline \multirow{3}{*}{$\begin{array}{l}\text { Sample } \\
\text { number }\end{array}$} & \multicolumn{4}{|c|}{ Abundance in weight percent } \\
\hline & Minor & & Trace & \\
\hline & $(1-10)$ & $(0.1-1.0)$ & $(0.01-0.1)$ & $(0.01)$ \\
\hline 410 & Alm & $\begin{array}{l}\text { Bio, Mon, } \\
\text { Py, Sill }\end{array}$ & $-\ldots$ & Moly \\
\hline $411 \mathrm{C}-\cdots$ & $-\cdots$ & $-\infty-\infty-$ & Alm, Ilm & $\begin{array}{l}\text { Rut, Py, } \\
\text { Monz }\end{array}$ \\
\hline 411D- - & Alm, Bio & $\begin{array}{l}\text { Mon, Uran, } \\
\text { Uph }\end{array}$ & $-\infty$ & Moly \\
\hline $415-$ & Alm, Tour & $-\cdots$ & Mag, Py & Mon, Col \\
\hline $417 A-\cdots$ & Alm & Bio & Uran & $\begin{array}{l}\text { Py, Mon, } \\
\text { Moly, Al }\end{array}$ \\
\hline 417B- - - & Apat & Uran & Alm & Py \\
\hline
\end{tabular}




\section{URANIUM FAVORABILITY}

Areas favorable for uranium deposits can be estimated by geochemical or geologic criteria. In the geochemical approach, plutonic rocks that contain anamalous amounts of uranium and thorium are considered to define a favorable area. The hypothesis behind this approach is that uraniferous rocks are a guide to, or genetically relatable to, uranium deposits. The type of genetic connection is not specified, and I believe that magmatic, hydrothermal, or supergene processes are permissible. The second approach is geologic, with geochemical input. Geologic enviroments are considered, either in relation to productive mines in the study area or to geologically similar productive areas elsewhere in the world. Both approaches yield results that are open to question as they are based on hypotheses and geologic estimates rather than fact.

Distribution of geochemically favorable granitic rocks.-Two levels of abnomality can be defined on the basis of uranium and thorium content and Th/ $U$. Marginally anomalous rocks are here defined as those with one or more of the following attributes: (1) Uranium content greater than the total population mean (8.83 ppm); (2) thorium content greater than the total population mean (20.3 ppm); and (3) Th/ $\mathrm{U}$ less than 2, a criterion that seems to predict uranium leachability. Using these criteria, 24 samples are determined to be marginally anamalous. Highly anomalous rocks are here defined as those with one or more of the following attributes: (1) Uranium content greater than the total population mean plus one standard deviation (15.8 ppm); (2) thorium content greater than the mean plus one standard deviation (30.3 ppm) and uranium content greater than the mean; and (3) Th/ $\mathrm{U}$ lower than the mean minus one standard deviation (1.68) and uranium content greater than the mean. According to these criteria 21 samples are considered to be highly ananalous.

The samples considered anomalous by geochemical criteria correspond very well with geologic units, as outlined very generally on figure 5. Four plutons seem to contain the highly anamalous samples, four plutons contain the marginally anomalous samples, and four granodiorite plutons 


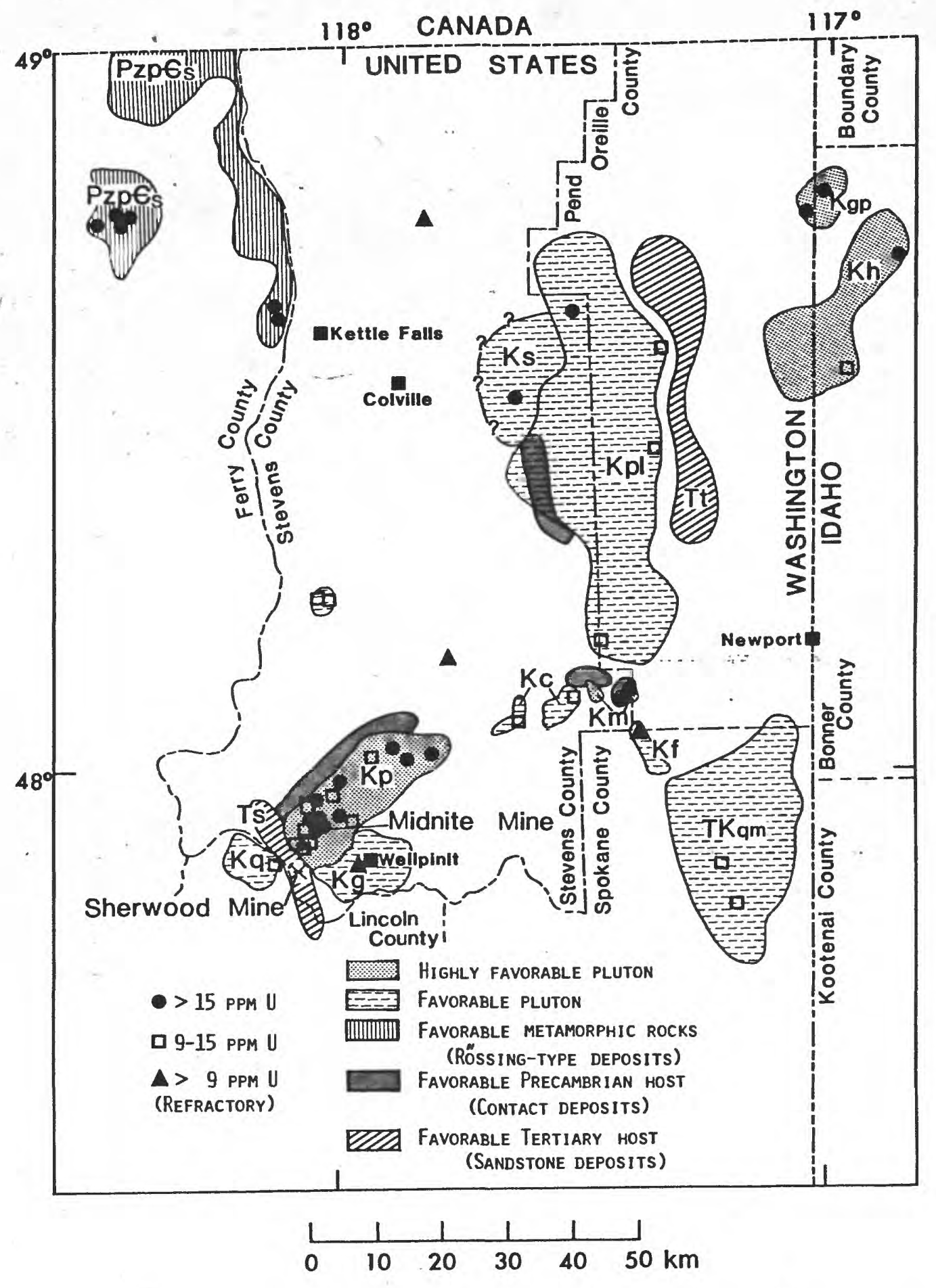

Figure 5.-- 
Figure 5.--Simplified geolgic map showing anomalous sample localities and anomalous plutons.

Rock unit abbreviations: Ts, Tertlary Sanpoil Volcanics; Tt, Tertiary Tiger Formation; Tkqm, Cretaceous(?) or Tertiary(?) quartz monzonite; $\mathrm{Kq}$, Cretaceous equigranular quartz monzonite; $\mathrm{Kg}$, Cretaceous granodiorite; $\mathrm{Kp}$, Cretaceous porphyritic quartz monzonite of the Midnite mine; Kf, Cretaceous Fan Lake Granodiorite; Km, Cretaceous muscovite quartz monzonite; Kpl, Cretaceous Philips Lake Granodiorite; Ks, Cretaceous Starvation Flat Quartz Monzonite; Kh, Cretaceous quartz monzonite of Hungry Mountain; Kgp, Cretaceous quartz monzonite of Granite Pass; PzpCs, Precambrian(?)-Paleozolc(?) metasedimentary rocks that correlate with the Shuswap Formation in British Columbia. 
contain one sample each that is typed as chemically anomalous but which I question on geologic grounds. The highly anomalous plutons are from south to north: (1) Cretaceous porphyritic quartz monzonite of the Midnite mine, mapped and described by Becraft and heis (1963) and Campbell and Raup (1964); (2) Cretaceous muscovite quartz monzonite (Miller, 1974c, Miller and Clark, 1975); (3) Cretaceous quartz monzonite of Hungry Mountain (Miller and Yates, 1976; F. K. Miller, oral commun., 1977); and (4) Cretaceous quartz monzonite of Granite Pass (Castor and others, 1977; F. K. Miller, oral commun., 1977). Marginally anomalous plutons include: (1) Cretaceous equigranular quartz monzonite (Becraft and Weis, 1963); Cretaceous coarse-grained quartz monzonite (Miller and Clark, 1975); Cretaceous Philips Lake Granodiorite (quartz monzonite in most places) (Miller and Clark, 1975; Miller, 1974a and 1974b); and (4) CretaceousTertiary biotite-muscovite quartz monzonite, with alaskite, of Mount Spokane (Weisenborn and weis, 1976). Some questionably anomalous plutons include: (1) Cretaceous granodiorite near Wellpinit (Becraft and Weis, 1963). (2) Jurassic granodiorite west of Waitts Lake (Miller and Engels, 1975; Miller and Yates, 1976); (3) Cretaceous Spirit pluton (Yates, 1971); and (4) Cretaceous Fan Lake Granodiorite (Miller, 1974c). Although one sample in each of these plutons is characterized as marginally ancmalous by the chemical criteria, these plutons are in the hornblende suite and much of their uranium is held in refractory accessories sphene and allanite.

Geologically favorable enviroments. - The study area includes rock types and geologic settings favorable for at least five types of uranium deposits that could be genetically related to plutonic rocks. The five I will consider are: (1) Rossing-type; (2) intragranitic hydrothermal veins of the French-type; (3) intragranatic supergene veins as at the Daybreak mine; (4) contact metasomatic deposits as at the Midnite mine; and (5) basal-type deposits in sandstone and conglomerate as at the Sherwood mine.

There is good potential for Rossing-type uranium deposits in the metamorphic rocks of the Kettle Mountains, northern Ferry County. The uraniferous leucogranite "pegmatite" and biotite schist, present together ; in migmatite, seem to resemble closely the lithologies and ores at the 
great Rossing deposit of Southwest Africa (Namibia) (Berning and others, 1976). The uranium-enriched rocks and occurrences seem to be chiefly in two stratigraphic zones. Uranium seens to have originally been in sedimentary rocks and subsequently concentrated by partial melting and metasomatism. There is little doubt that there is abundant uranium in the metamorphic camplex, but economic viability of any deposit remains to be proven as known grades over mining widths and tonnages are low. The area suffers from a lack of supergene enrichment, a process that probably upgraded the primary mineralization of the Rossing deposit (Jacob and Hambleton-Jones, 1977). Rocks that may have been supergene enriched in the Kettle Mountains were stripped away by glacial scouring. Further exploration might locate thicker zones of disseminated Rossing-type mineralization or possibly structurally controlled zones with higher grades than presently known.

Another area with possible potential for Rossing-type deposits is that high-grade metamorphic rocks containing migmatite in the Greenacres (Weis, 1968) and Mount Spokane (Weissenborn and We is, 1976) quadrangles. I am not aware, however, of any abnormally radioactive rocks in this terrane. There are numerous dikes of alaskite and pegmatite within the Philips Lake Granodiorite (Miller and Clark, 1975; Miller, 1974b, 1974c), and some of the leucocratic rocks are radioactive, but this is not a migmatite complex as at Rossing and thus is not the same geologic enviroment.

The Mount Spokane area has been cited as favorable for "porphyry" type uranium deposits (Armstrong, 1974). The concept behind "porphyry" uranium deposits is fundamentally economic, emphasizing the large tonnage, low-grade character that is amenable to mass mining. Geologically the archetype is the Rossing deposit. The Mount spokane example remains to be proven in an economic sense, but the geologic envirorment is plutonic, not metamorphic. Also, the pegmatites and alaskites on Mount Spokane are less rich in uranium than the enclosing quartz monzonite, according to my investigations and those of several industry geologists. In my opinion, application of the Rossing analog to Mount spokane yields erroneously favorable resource estimates. 
Vein-type deposits of hydrothermal or supergene origin are possibly within granitic plutons of the study area. Predictions regarding hydrothemal veins are best made by making analogies with the deposits in the French Massif Centrale. Recent studies demonstrate that the French examples are hydrothemal rather than supergene (Poty and others, 1974; Cuney, 1978; Leroy, 1978). The supergene veins are best compared with the Daybreak deposit on Mount Spokane (Norman, 1957; Weissenborn and Weis, 1976). I consider the vein deposits on Mount Spokane to be of supergene origin because the deposits generally occur within $100 \mathrm{ft}(30 \mathrm{~m})$ of the surface, above or within the fluctuating water table, and consist predominantly of meta-autunite, a hexavalent uranium phosphate mineral.

The hydrothermal intragranitic veins are well known from France where they form in two-mica granitic plutons chemically similar to many of the two-mica plutons in the study area. The complex fracturing and episyenite alteration (desilicification) characteristic of the French examples has not been documented within the study area. I have heard of one unconfirmed report of episyenite alteration of plutonic rocks in the area. The upper portions of some of the uraniferous two-mica plutons seem generally favorable for French-type intragranitic veins, but we lack knowledge of specific structural or alteration guides. No faults are shown within plutons on published 1:62,500 maps in the study area, a testimonial to the typically poor exposures; thus location of possible vein deposits would be difficult. The four highly uraniferous plutons (fig. 5) should be the best exploration areas for hydrothermal veins.

Intragranitic vein deposits of uranium formed from supergene fluids probably occur in the study area. In addition to the obvious need for a uranium source and a structure, hydrologic conditions must be appropriate for uranium enrichment and preservation. Rugged topography probably is not favorable for these deposits as a relatively stable, albeit fluctuating, water table seems to be required. In the Mount Spokane area most autunite deposits occur in ridges or upland meadows with relatively little relief, a condition that probably stabilizes the water table. Deep weathering in Miocene time appears to be a factor in the genesis of the autunite deposits on Mount Spokane (Weissenborn and Weis, 1976). The coarse-grained quartz monzonite near Loon Lake and the quartz monzonite of 
Hungry Mountain along the Idaho-Washington border, as well as the biotitemuscovite quartz monzonite and associated alaskite of Mount Spokane appear to have appropriate physiography, deep weathering, and uranium content to be favorable for supergene vein deposits. Portions of the porphyritic quartz monzonite of the Midnite mine with low relief should also be favorable.

The fourth possible enviroment is in contact metamorphic zones adjacent to plutons, as at the Midnite mine (Nash, 1977A). Criteria (Nash, 1977A) for this type of deposit include: (1) uraniferous pluton with evidence (such as porphyritic texture, aplite, or pegmatite) of water-pressure release; (2) pre-intrusion faults; and (3) reactive wallrocks containing reductants such as sulfide minerals, and possibly graphite of high temperature I favor hydrothermal emplacement of uranium at the Midnite mine, but supergene emplacement at the Midnite mine and elsewhere is certainly possible. Supergene deposition in contact zones would probably be mainly a chemical and hydrologic problem, similar to the supergene veins described previously, and would not require reducing minerals in wallrock for hexavalent uranium ores to form.

Contact-metasomatic deposits containing pitchblende, as at the Midnite mine, are most likely to occur in rocks of the Precambrian Belt Supergroup, although some Paleozoic sulfidic-graphitic shales and phyllites are a less well known possibility. The most favorable areas, seem to be: (1) Precambrian Togo Formation adjacent to the porphyritic quartz monzonite of the Midnite mine in the five townships included in $\mathrm{T}$. 28 and 29 N., R. 37 and 39 E. (Becraft and Weis, 1963; Campbell and Raup, 1964; Miller and Yates, 1976). (2) Precambrian Prichard and Wallace Formations adjacent to coarse-grained quartz monzonite and muscovite quartz monzonite near Deer Lake in T. 30 N., R. 41 and $42 \mathrm{E}$. (Miller, 1974c; Miller and Clark, 1975); and (3) a large area, presently unmapped, containing Belt rocks including sulfidic Prichard Formation, adjacent to the quartz monzonite of Hungry Mountain and quartz monzonite of Granite Pass in northern Idaho, T. 61 and 63 N., R. 5 W. Another area that might be favorable for contact deposits is on the western contact of the Philips Lake Granodiorite northeast of Colville in T. 33 and 34 N., R. 41 and 42 E. (Miller and Clark, 1975; note that the preliminary map by Clark and Miller (1968), shows the Belt as undifferentiated). 
The fifth type of uranium enviroment is Tertiary sandstone and conglomerate as at Sherwood mine, Stevens County (previously called the Northwest mine in Becraft and Weis, 1963). Similar deposits occur in the Okanogan Valley of British Columbia and have been termed "basal-type" deposits because they occur in poorly consolidated Tertiary sediments unconformably overlying basement rocks as at the Sherwood deposit (Christopher, 1977). Uranium favorability of Tertiary sedimentary rocks within the study area has been investigated by Marjaniemi and Robins (1975a, 1975b, 1975c) but little importance given to the character of adjacent plutonic rocks that could be potential source rocks. The only area in which Tertiary clastic rocks are adjacent to one of the highly uraniferous plutons is in the Sherwood mine area (Tertiary Sampoil Volcanics or Gerome Volcanics of former usage, Becraft and Weis, 1963). Another possibly favorable area is in the Tertiary Tiger Formation adjacent to the Philips Lake Granodiorite (Miller, 1974b), between Tiger and Cusick. Highly uraniferous quartz monzonite of Hungry Mountain presently is in a watershed that drains eastward into Idaho rather than into the Pend Oreille Valley and probably cannot be considered as a source of uranium for deposits in the Tiger Formation. A plutonic source-rock criterion, suggested here, could be added to the criteria of Marjaniemi and Robins (1975c) and improve the favorability rating of the Tiger and cusick areas to high or very high. The granitic source area is not nearly as good, however, as that of the porphyritic quartz monzonite of the Midnite mine which is the prime source for the Sherwood area.

I have no observations that bear on favorability of Tertiary clastic rocks in the upper Columbia River Valley or Republic graben (Marjaniemi and Robins, 1975b). None of the anomalous rocks located in this study appears to be a source for possible uranium deposits in those rocks. 


\section{REFERENCES}

Armstrong, F. C., 1974, Uranium resources of the future "porphyry" uranium deposits, in Formation of uranium ore deposits: Vienna, International Atamic Energy Agency, SM-183/12, p. 625-635.

Barbier, Jean, and Ranchin, Guy, 1969, Influence de l'alteration meteorique sur l'uranium a l'etat de traces dans le granite a deux micas de $S t$. Sylvestre: Geochimica et Cosmochimica Acta, v. 33, p. 39-47.

Barlow, J. L., 1958, Some uranium occurrences in northern Ferry County, Washington: U.S. Atamic Energy Commission RME-2068, 22 p.

Becraft, G. E., and Weis, P. L., 1963, Geology and mineral deposits of the Turtle Lake Quadrangle, Washington: U.S. Geological Survey Bulletin 1131, 73 p., scale $1: 62,500$.

Berning, J., Cooke, R., Hiemstra, S. A., and Hoffman, U., 1976, The Rossing uranium deposit, South West Africa: Econamic Geology, v. 71, p. 351-368.

Buddington, A. F., 1959, Granite emplacement with special reference to North America: Geological Society America Bulletin, v. 70, p. 671-748.

Campbell, A. B., and Raup, O. B., 1964, Preliminary geologic map of the Hunters quadrangle, Stevens and Ferry Counties, Washington: U.S. Geological Survey Mineral Investigations Map MF-276, scale 1:48,000.

Castor, S. B., Berry, M. R., and Robins, J. W., 1977, Preliminary report on uranium and thorium content of intrusive rocks in northeastern washington and northern Idaho: U.S. Energy Research and Development Administration Report GJBX-89(77)R, 40 p.

Chappel, B. W., and White, A. F. R., 1974, Two contrasting granite types [abs.]: Pacific Geology, v. 8, p. 173-174.

Cheney, E. S., 1977, Uranium deposits in the Shuswap rocks of the Kettle Dome, Ferry County, Washington [abs.]: in Symposium on Uranium Exploration in the Pacific Northwest, Eastern Washington University, Cheney, p. 7. Christopher, P. A., 1977, Basal-type uranium deposits of the Okanogan Valley in British Columbia [abs.], in Symposium on uranium exploration in the Pacific Northwest: Eastern Washington University, Cheney, p. 7. 
Clark, L. D., and Miller, F. K., 1968, Geology of the Chewelah Mountain Quadrangle, Stevens County, Washington: Washington Division of Mines and Geology Map GM-5, scale 1:62,500.

Cuney, Michel, 1978, Geologic envirorment, mineralogy, and fluid inclusions of the Bois Noirs Limouzat uranium vein, Forez, France: Economic Geology, v. 73 , no. 8 , in press.

Darnley, A. G., Charbonneau, B. W., and Richardson, K. A., 1977, Distribution of uranium in rocks as a guide to the recognition of uraniferous regions, in Recognition and evaluation of uraniferous areas: Vienna, International Atomic Energy Agency, TC-25/9, p. 55-86.

Dodson, R. G., Needham, R. S., Wilkes, P. G., Page, R. A., Smart, P. G., and Watchman, A. L., 1974, Uranium mineralization in the Rum Jungle-Alligator Rivers Province, Northern Territory, Australia, in Formation of uranium ore deposits: Atomic Energy Agency, Vienna, p. 551-568.

Jacob, R. E., and Hambleton-Jones, B. B., 1977, Geological and geochenical setting of granites in the eugeosynclinal portion of the Damara Orogen, Rossing area, South West Africa [abs.]: Geological Society of America Abstracts with programs, v. 9, p. 1,035.

Lee, D. E., and Dodge, F. C. W., 1964, Accessory minerals in some granitic rocks in California and Nevada as a function of calcium content: American Mineralogist, v. 49, p. 1,6760-1,669.

Leroy, Jacques, 1978, The Margnac and Fanay uranium deposits of the LaCrouzille District (Western Massif-Central, France): Geologic and fluid-inclusion studies: Economic Geology, v. 73, no. 8 , in press.

Marjaniemi, D. K., and Basler, A. L., 1972, Geochemical investigations of plutonic rocks in the western United States for the purpose of determining favorability for vein-type uranium deposits: U.S. Atomic Energy Commission Report GJO-912-16, 181 p.

Marjaniemi, D. K., and Robins, J. W., 1975a, Uranium favorability of Tertiary sedimentary rocks of the lower Spokane River Valley and of northern Spokane County, Washington: U.S. Energy Research and Development Administration Report GJBX-1(76), 48 p. 1975b, Uranium favorability of Tertiary sedimentary rocks of the western 
Okanogan highlands and of the upper Columbia River Valley: U.S. Energy Research and Development Administration Report GJBX-3(76), 71 p. 1975c, Uranium favorability of Tertiary sedimentary rocks of the Pend Oreille River Valley, Washington: U.S. Energy Research and Development Administration Report GJBX-3(76), 50 p.

Miller, F. K., 1974a, Preliminary geologic map of the Newport Number 1 Quadrangle, Pend Oreille county, Washington, and Bonner County, Idaho: Washington Division Geology and Earth Resources Map GM-7, scale 1:62,500.

1974b, Preliminary geologic map of the Newport Number 2 Quadrangle, Pend Oreille and Stevens Counties, Washington: Washington Division Geology and Earth Resources Map GM-8, scale 1:62,500.

1974c, Preliminary geologic map of the Newport Number 3 Quadrangle, Pend Oreille, Stevens, and Spokane Counties, Washington: Washington Division Geology and Earth Resources Map GM-9, scale 1:62,500.

1974d, Preliminary geologic map of the Newport Number 4 Quadrangle, Spokane and Pend Oreille Counties, Washington, and Bonner County, Idaho: Washington Division Geology and Earth Resources Map GM-10, scale 1:62,500.

Miller, F. K., and Clark, L. D., 1975, Geology of the Chewelah-Loon Lake area, Stevens and Spokane Counties, Washington: U.S. Geological Survey Professional Paper 806, 74 p, scale 1:62,500.

Miller, F. K., and Engels, J. C., 1975, Distribution and trends of discordant ages of plutonic rocks of northeastern Washington and northern Idaho: Geological Society of America Bulletin, v. 86, no. 4, p. 517-528.

Miller, F. K., and Yates, R. G., 1976, Geologic map of the west half of the Sandpoint $1^{\mathrm{O}} \times 2^{\mathrm{O}}$ Quadrangle, Washington: U.S. Geological Survey Open-File Report 76-327, scale 1:125,000.

Moreau, Marcel, Paughon, Andre, Puybaraud, Yves, and Sanselme, Henri, 1965, L'uranium et les granites, Chronique des Mines et de la Recherche Minere, no. 350, p. $47-50$.

Muessig, Siegfried, 1967, Geology of the Republic Quadrangle and a part of the Aeneas Quadrangle, Ferry County, Washington: U.S. Geological Survey Bulletin 1216, 135 p., scale 1:62,500.

Munroe, R. J., Sass, J. H., Bunker, C. M., and Bush, C. A., 1975, Abundances of 
uranium, thorium and potassium from some plutonic rocks in northern Washington: U.S. Geological Survey Open-File Report 75-221, 14 p.

Nash, J. T., 1977a, Geology of the Midnite uranium mine area, Washington--maps, description, and interpretation: U.S. Geological Survey Open-File Report $77592,39 \mathrm{p}$.

1977b, Uranium in Precambrian granitic rocks of the St. Francois Mountains, southeastern Missouri, with comments on uranium resource potential: U.S. Geological Survey Open-File Report 77-787, 33 p.

Nininger, R. D., 1977, Recognition of uranium districts, in Recognition and evaluation of uraniferous areas: Vienna, International Atamic Energy Agency, TC-25/1, p. 1-11.

Norman, H. W., 1957, Uranium deposits of northeastern Washington: Mining Engineering, v. 9, no. 6, p. 662-666.

Parker, R. L., and Calkins, J. A., 1964, Geology of the Curlew Quadrangle, Ferry County, Washington: U.S. Geological Survey Bulletin 1169, 95 p., scale $1: 62,500$.

Pearson, R. C., 1977, Preliminary geologic map of the Togo Mountain Quadrangle, Ferry County, Washington: U.S. Geological Survey Open-File Report 77-371, $1 \mathrm{pl}$., scale 1:62,500.

Phair, George, and Gottfried, David, 1964, The Colorado Front Range, Colorado, U.S.A., as a uranium and thorium province, in The National Radiation Environment: University of Chicago Press, p. 7-38.

Poty, B. P., Leroy, Jaques, and Cuney, Michel, 1974, Les inclusions fluids dans les minerais des gisements d'uranium intragranitiques du Limousin et du Forez (Massif Central, France), in Formation of uranium deposits: Vienna, International Atomic Energy Agency, SM-183/17, p. 569-582.

Poty, B. P., and others, 1977, Report of Panel II, Uranium distribution within the earth's crust and rocks as a guide for prospecting, in Recognition and evaluation of uraniferous areas: Vienna, International Atomic Energy Agency, p. 285-288.

Richardson, K. A., 1964, Thorium, uranium, and potassium in the Conway Granite, New Hampshire, U.S.A., in Adams, J. A. S., and Lower, W. M., eds., The natural radiation enviroment: Chicago, University of Chicago Press, 
p. 51-62.

Rogers, J. J. W., and Adams, J. A. S., 1969, "Thorium," Chapt. 90, in Wedepohl, K. H., ed., Handbook of geochemistry: Berlin, Springer-Verlag, v. II-4. Simpson, P. R., Plant, Jane, and Cope, M. J., 1977, Uranium abundance and distribution in some granites from northern Scotland and southwest England as indicators of uranium provinces, in Jones, M. J., ed., Geology, mining, and extractive processing of uranium: London, The Institution of Mining and Metallurgy, p. 126-139.

Stuckless, J. S., Bunker, C. M., Bush, C. A., Doering, W. P., and Scott, J. H., 1977a, Geochemical and petrologic studies at a uraniferous granite from the Granite Mountains, Wyoming: U.S. Geological Survey Journal of Research, v. 5, p. 61-81.

1977b, A comparison of some analytical techniques for determining uranium, thorium, and potassium in granitic rocks: U.S. Geological Survey Journal of Research, v. 5, p. 83-91.

Stuckless, J. S., and Ferreira, C. P., 1976, Labile uranium in granitic rocks, in Exploration for uranium ore deposits: Vienna, International Atanic Energy Agency, AM-208/17, p. 717-730.

Stuckless, J. S., and Nkomo, I. T., 1978, Uranium-lead isotope systematics in uraniferous alkali-rich granites from the Granite Mountains, Wyoming, in Implications for uranium source rocks: Econ. Geology, v. 73, p. 427-441. Weis, P. L., 1968, Geologic map of the Greenacres Quadrangle, Washington and Idaho: U.S. Geological Survey Geologic Quadrangle Map GQ-734, scale $1: 62,500$.

Weissenborn, A. E., and Weis, P. L., 1976, Geologic map of the Mount Spokane Quadrangle, Spokane County, Washington, and Kootenai and Bonner Counties, Idaho: U.S. Geological Survey Geologic Quadrangle Map GQ-1336, scale $1: 62,500$.

White, A. J. R., and Chappel, B. W., 1977, Ultrametamorphism and granitoid genesis: Tectonophysics, v. 43, p. 7-22.

Yates, R. G., 1971, Geologic map of the Northport Quadrangle, Washington: U.S. Geological Survey Miscellaneous Investigations Map I-603, scale 1:31,680. 